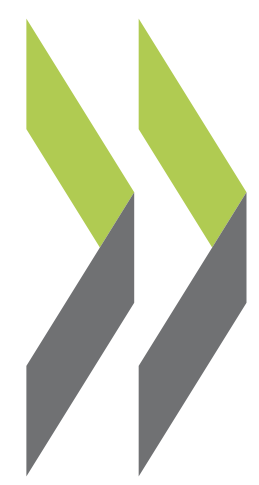

OECD Economics Department Working Papers No. 827

Resolving and Avoiding Unsustainable Imbalances

\title{
Sebastian Barnes
}

\author{
in the Euro Area
}


Organisation de Coopération et de Développement Économiques

Organisation for Economic Co-operation and Development

09-Dec-2010

ECONOMICS DEPARTMENT

English - Or. English

RESOLVING AND AVOIDING UNSUSTAINABLE IMBALANCES IN THE EURO AREA

ECONOMICS DEPARTMENT WORKING PAPER No. 827

By Sebastian Barnes

All Economics Department Working Papers are available throught OECD's internet web site at www.oecd.org/Working_Papers

JT03294212

Document complet disponible sur OLIS dans son format d'origine

Complete document available on OLIS in its original format 


\section{ABSTRACT/RÉSUMÉ}

\section{Resolving and avoiding unsustainable imbalances in the euro area}

Some euro area countries accumulated large and persistent external imbalances during the upswing, revealing important weaknesses in the macroeconomic management of the monetary union. Greece, Ireland, Portugal and Spain ran large current account deficits by historical standards, while Finland, Germany and the Netherlands had substantial surpluses. Some of these deficits and surpluses were larger than appear justified by economic fundamentals. The massive debt accumulation made deficit economies vulnerable to shocks, complicated their recovery from the world financial crisis, and has challenged the stability of the euro area. In some countries, fiscal policy in the past decade failed to counter and sometimes aggravated these pressures.

External imbalances were driven by underlying domestic economic, financial and sometimes fiscal imbalances. These were the result of a combination of a wide range of country-specific shocks and insufficient macroeconomic and financial stabilisation. Movements in real interest rates in some countries contributed to diverging borrowing and saving patterns, which fuelled credit booms and a weakening of competitiveness in some deficit countries. Weaknesses in financial regulation and over-optimistic growth expectations encouraged excessive risk-taking in both deficit and surplus countries.

Harmful imbalances can be characterised by a misallocation of resources and increased vulnerability. When the financial crisis hit, some deficit countries faced the combined problems of a sharp contraction in private demand, an impaired financial system and weak public finances. Unwinding large imbalances, in both deficit and surplus countries, will be a prolonged and difficult process.

A new and cross-cutting approach to economic and financial management in the euro area is required to ensure balanced development in the future. While the shocks that led to this build-up of imbalances may not recur, similar pressures are likely to arise within the monetary union in the future. Macroeconomic, financial and fiscal management should be strengthened in an integrated way, alongside structural reforms. This should aim to achieve the differentiation necessary to improve stabilisation of national economies, while ensuring that the euro area as a whole is protected from unsustainable developments in individual countries. Important legislative changes are underway at EU level to improve the surveillance of imbalances and to help ensure that the necessary corrective action is undertaken where risks emerge.

This working paper relates to the 2010 OECD Economic Survey of the Euro Area (www.oecd.org/eco/surveys/euroarea).

JEL classification: F32; F36; F41

Keywords: euro area; monetary union; current account; imbalances; credit booms; competitiveness

\section{Résorber et éviter les déséquilibres non soutenables dans la zone euro}

Certains pays de la zone euro ont accumulé des déséquilibres extérieurs importants et persistants durant la phase d'expansion, qui ont mis au jour de sérieuses déficiences dans la gestion macroéconomique de l'union monétaire. L'Espagne, la Grèce, l'Irlande et le Portugal ont enregistré des déficits de balance courante élevés par rapport aux périodes passées, alors que l'Allemagne, la Finlande et les Pays-Bas ont affiché des excédents substantiels. Certains de ces déficits et excédents étaient plus prononcés que ne le justifiaient, semble-t-il, les fondamentaux économiques. L'accumulation massive de la dette a rendu les économies déficitaires vulnérables face aux chocs, compliqué leur redressement après la crise financière mondiale et remis en cause la stabilité de la zone euro. Dans certains pays, la politique budgétaire n'a pu contrecarrer et a parfois même aggravé ces tensions.

Les déséquilibres extérieurs ont été nourris par des déséquilibres internes sous-jacents, dans les domaines économique, financier et parfois budgétaire, imputables à la fois à une série de chocs par pays et à une stabilisation macroéconomique et financière insuffisante. Les variations des taux d'intérêt réels dans certains pays ont contribué à des profils d'emprunt et d'épargne divergents qui ont alimenté une forte expansion du crédit et suscité un affaiblissement de la compétitivité dans plusieurs pays déficitaires. Les déficiences de la réglementation financière et les anticipations de croissance exagérément optimistes ont encouragé une prise de risques excessifs dans les pays déficitaires comme dans les pays excédentaires.

Les déséquilibres néfastes impliquent des distorsions dans l'allocation des ressources et une vulnérabilité accrue. Lorsque la crise financière a frappé, certains pays déficitaires ont été confrontés à une combinaison de problèmes : forte contraction de la demande privée, défaillance du système financier et fragilité des finances 
publiques. La correction des déséquilibres extérieurs, dans les pays déficitaires comme dans les pays excédentaires, sera longue et difficile.

Une nouvelle approche pluridisciplinaire de la gestion économique et financière dans la zone euro s'impose pour assurer un développement équilibré à l'avenir. Les chocs qui ont conduit à cette accumulation de déséquilibres ne se reproduiront pas nécessairement, mais des pressions du même type apparaîtront vraisemblablement au sein de l'union monétaire. La gestion macroéconomique, financière et budgétaire devra être renforcée de façon intégrée, parallèlement à la mise en œuvre de réformes structurelles. La différenciation nécessaire à une plus grande stabilisation des économies nationales pourra ainsi être assurée, tout en garantissant la protection de la zone euro dans son ensemble contre les évolutions peu viables intervenant dans les différents pays. D'importantes modifications législatives sont engagées au niveau de l'UE pour améliorer la surveillance des déséquilibres et veiller à ce que les mesures correctrices nécessaires soient engagées lorsque des risques se manifestent.

Ce document de travail porte sur l'Étude économique du Zone euro.

(www.oecd.org/eco/etudes/zoneeuro).

Classification JEL : F32 ; F36 ; F41

Mots clés : zone euro ; union monétaire ; solde extérieure ; déséquilibres ; expansion du crédit ; compétitivité

Copyright OECD 2010

Application for permission to reproduce or translate all, or part of, this material should be made to: Head of Publications Service, OECD, 2 rue André-Pascal, 75775 Paris Cedex 16, France 


\section{TABLE OF CONTENTS}

Resolving and avoiding unsustainable imbalances in the euro area.........................................................

Large and persistent external imbalances built up during the upswing ....................................................

External balances have been driven by internal economic and financial imbalances ............................... 8

Fundamentals only explain part of external imbalances in the euro area ........................................... 8

Imbalances arose from diverging economic pressures and domestic imbalances................................ 10

Fiscal policy failed to prevent or even contributed to the build-up of imbalances ................................ 13

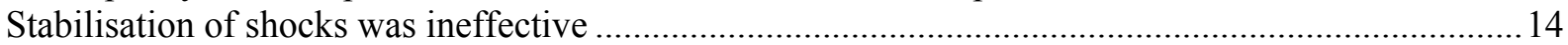

Domestic savings and investment imbalances led to large changes in balance sheets ..........................18

Housing booms and credit cycles aggravated imbalances .................................................................19

Imbalances in some countries had spillovers for other monetary union economies ..............................23

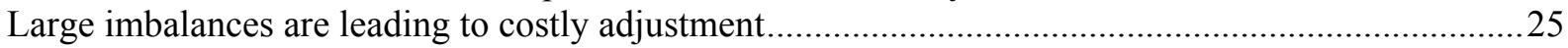

Measures to restore stability in the near and longer term are needed at European and national level ......26

Restoring macroeconomic and financial stability is an immediate priority ........................................2

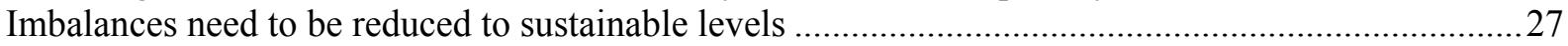

Improving national macroeconomic and financial management to avoid future imbalances ................29

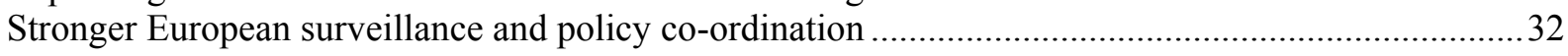

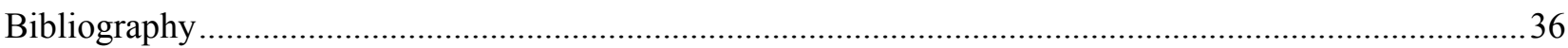

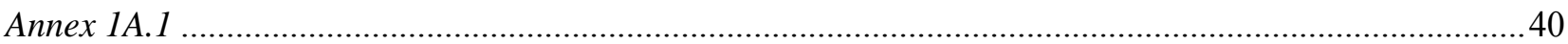

\section{Tables}

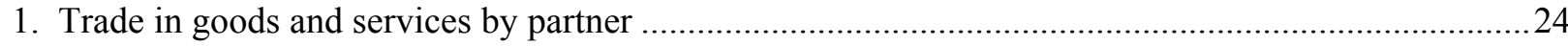

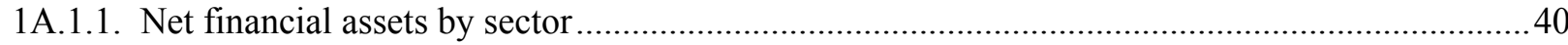

\section{Figures}

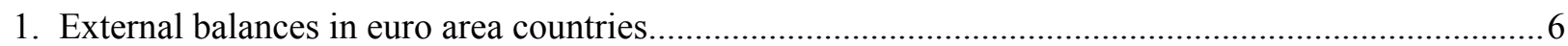

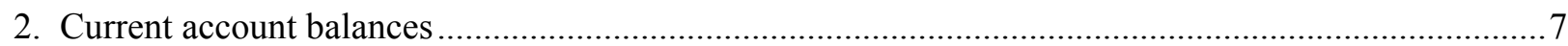

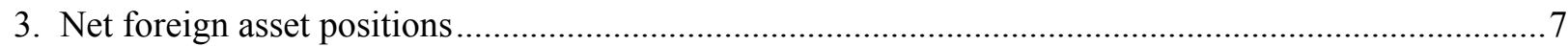

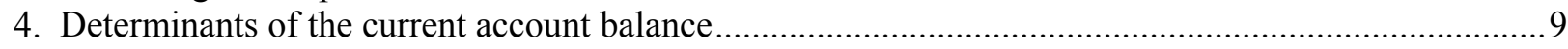

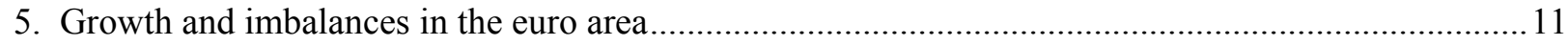

6. External balances, interest rate gaps and competitiveness.............................................................. 15

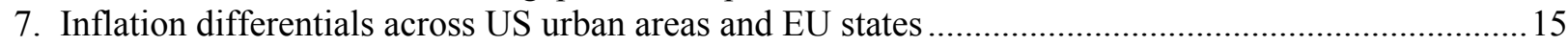

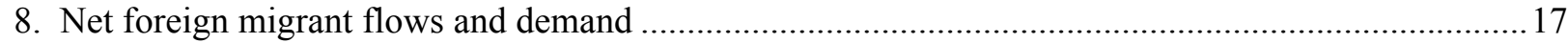

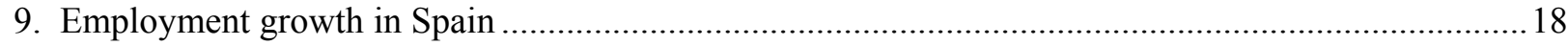

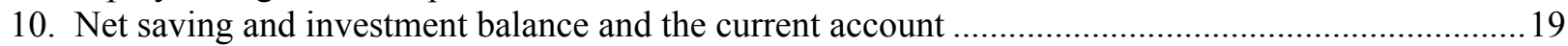

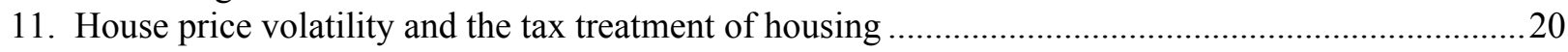

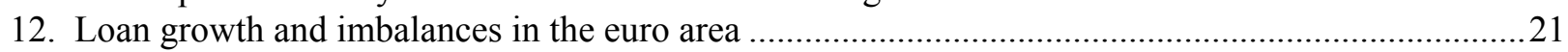

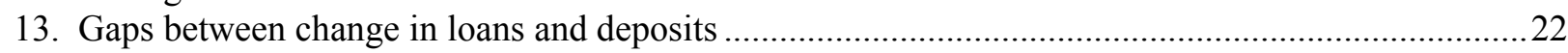

14. Deficit countries are experiencing the largest overall adjustment ..................................................25

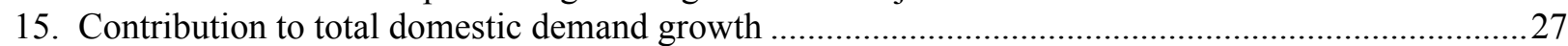

\section{Boxes}

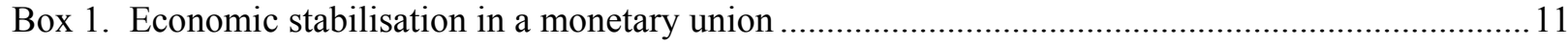

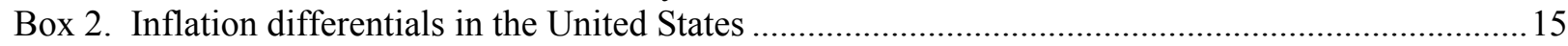

Box 3. Economic adjustment through migration to overheating economies .........................................17 


\title{
Resolving and avoiding unsustainable imbalances in the euro area
}

\author{
By Sebastian Barnes ${ }^{1}$
}

Large and persistent intra-euro area imbalances built up during the economic upswing, creating tensions that contributed to the economic and financial crisis, although the euro area as a whole was close to current account balance. This paper begins by analysing how far these current account imbalances reflected the efficient operation of a monetary union and to what extent these imbalances may have been excessive. There were large current account surpluses and deficits in some euro area countries as the result of internal economic, financial and fiscal imbalances, combined with structural misalignments and rigidities. The stabilisation of underlying shocks was ineffective and real interest rates divergences sometimes played a destabilising role, particularly in deficit countries where easy borrowing conditions led to credit and house-price cycles combined with an erosion of price competitiveness. The search for high yields acted as an incentive to excessive risk-taking in surplus countries. Excess saving in surplus countries was channelled through capital markets into deficit countries: while this process could in principle facilitate the efficient allocation of capital, there was a misallocation of capital due to weaknesses in financial regulation and expectations that turned out to be too optimistic.

The second section of the paper sets out the immediate need to resolve the existing imbalances, beginning by stabilising the financial sector and public finances of countries that have suffered the most severe downturns. Although there were idiosyncratic features to the imbalances over the past decade, similar pressures are likely to arise again within the monetary union. A new and cross-cutting approach is required to prevent excessive imbalances arising to the same extent in the future. This should rest on a broad range of policies to address the sources of imbalances, including sound fiscal policy and more effective macroprudential policies, supported by structural reforms. It is essential that policy settings are more differentiated across countries, while ensuring that the euro area as a whole is protected from unsustainable positions at national level. There is a role for enhanced surveillance of imbalances at Euro Group and EU levels.

\section{Large and persistent external imbalances built up during the upswing}

Some euro area countries ran very large current account imbalances during the upswing, which were among the largest in OECD countries. From 2002 to 2007, the current account deficits in Greece,

1. The author is an economist in the Economics Department of the OECD. This paper is based largely on work originally prepared for the Economic Survey of the Euro Area published on 13 December 2010 under the authority of the Economics and Development Review Committee (EDRC). The author would like to thank Piritta Sorsa, Andrew Dean and colleagues in the Economics Directorate of the OECD for comments on earlier drafts, but retains full responsibility for any errors or omissions. Thanks to Daniele Siena for useful inputs, to Isabelle Duong for excellent technical assistance and to Deirdre Claassen for technical preparation. 
Portugal and Spain averaged over 7\% of national GDP (Figure 1, upper panel). ${ }^{2}$ By contrast, Finland, Germany and the Netherlands ran average surpluses of over 5\% of GDP. Deficits were not primarily financed by foreign direct investment (FDI). As the aggregate euro area current account position was close to balance, the borrowing of countries such as Italy and Spain effectively largely counterbalanced large German and, to a lesser extent, Dutch surpluses (Figure 1, lower panel). Since the beginning of the financial crisis, the dispersion of current account balances has narrowed considerably with some reduction in surpluses and, with the collapse in domestic demand, a more marked narrowing of deficits, notably in Spain (OECD, 2010a).

Figure 1. External balances in euro area countries
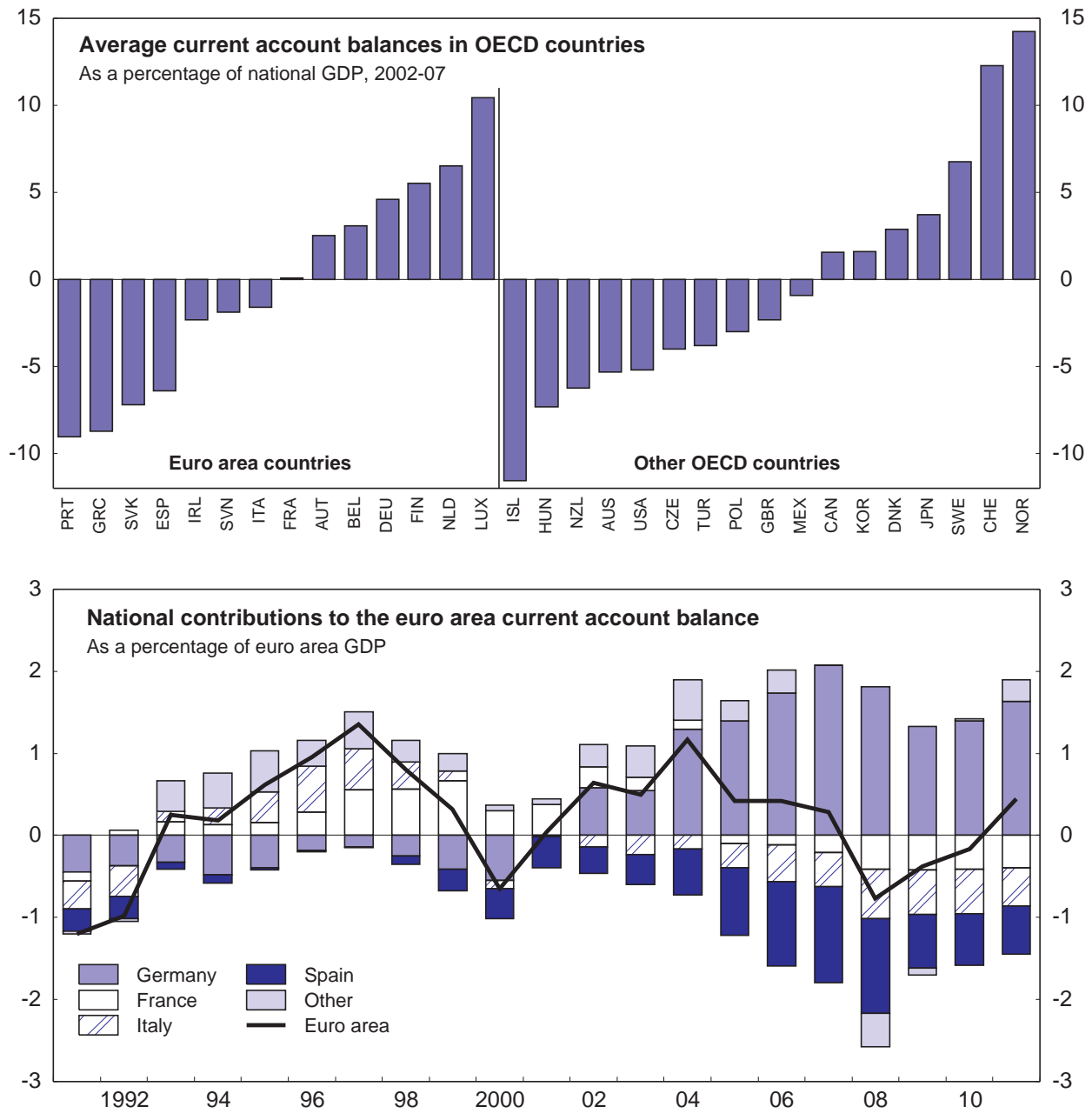

Source: OECD, OECD Economic Outlook 88 Database.

The scale and persistence of the imbalances was greater than in earlier decades (Figure 2). In 1998 , current account imbalances in the euro area countries ranged from $-5 \%$ to $7 \%$ of GDP with the average absolute imbalance at $3 \%$ of GDP. By 2007 , the range had widened to $-14 \%$ to $8 \%$ of GDP and the average absolute imbalance had doubled to $6 \%$ of GDP. Although euro area countries have experienced large imbalances in the past, with Ireland and Portugal for example running very large

2. As Slovenia and Slovakia only joined the euro area in 2007 and 2009 respectively, they are excluded from the analysis below which focuses on the build-up of imbalances during the 2000s. 
deficits in the early 1980s, the broad-based widening of external imbalances during the upswing was new.

Figure 2. Current account balances ${ }^{1}$

As a percentage of national GDP

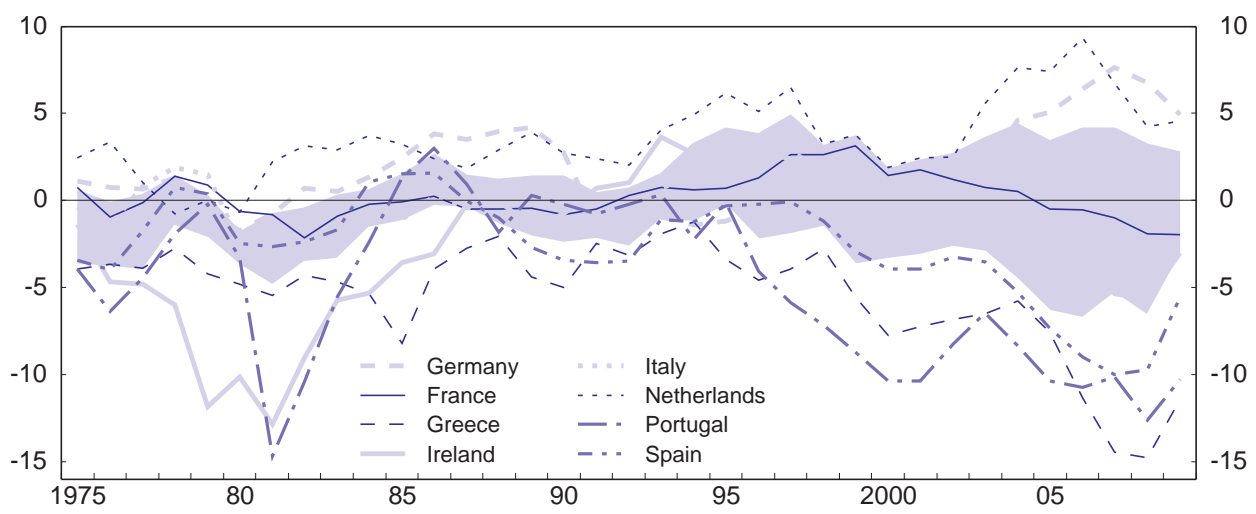

1. The shaded area indicates the range between the 25th and 75th percentiles.

Source: OECD, OECD Economic Outlook Database.

The large imbalances contributed to a wide dispersion of net international liabilities. Greece, Portugal and Spain had accumulated net foreign liabilities of over $70 \%$ of national GDP by 2008 (Figure 3). This degree of external indebtedness was among the highest in the OECD and large by the historical experience of euro area countries. Only Finland had previously experienced a similar situation, following the collapse of the Soviet Union. Net foreign asset positions in creditor euro area countries also reached a high level with a net positive position of $20 \%$ of GDP in Germany and more than $40 \%$ in Belgium and Luxembourg. ${ }^{3}$ The net asset positions as a share of GDP of the latter three countries are similar to those of Japan and Norway. The euro area as a whole was close to balance in terms of the net foreign asset position as the large internal imbalances were largely offsetting. However, the absolute size of the net asset positions of some countries was significant in global terms: Germany's net foreign asset position in 2008 was just under $40 \%$ of the size of Japan's in dollar terms and around $60 \%$ of China's.

Figure 3. Net foreign asset positions

As a percentage of GDP, 2008

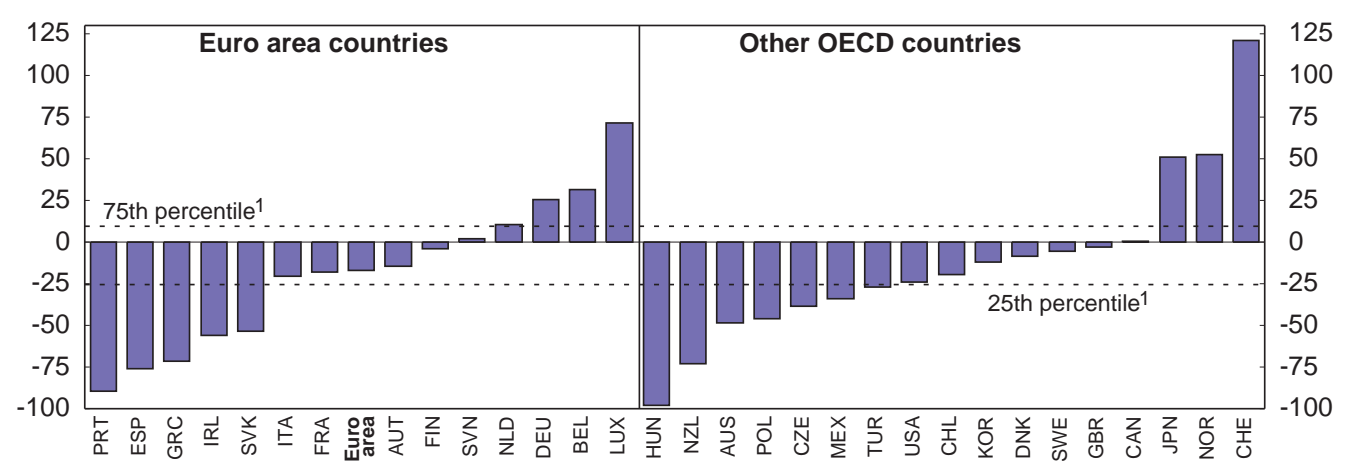

1. Calculated for the period 1985-2008 with Australia (1986-2008), Austria, Belgium, Canada, Finland, France (1989-2008), Germany, Italy, Japan, Netherlands, New Zealand (1989-2008), Spain, Sweden, Switzerland, United Kingdom and United States.

Source: IMF, International Financial Statistics.

3. Based on IMF International Financial Statistics. There are alternative measures of net international investment positions. 
The changes in net external positions over the period 2002 to 2007 were marked. Net foreign asset positions in Portugal and Spain each declined by around 25 percentage points of GDP, while Germany increased its net position as a share of its GDP by close to 20 percentage points. There was also a large deterioration in France. Countries with external debts in 2002 tended to run large deficits, while creditor countries tended to run surpluses, exacerbating the initial differences in net foreign assets positions. This effect only partly stems from the inclusion in the current account of interest payments being paid on existing debt or income earned on net foreign assets. The changes in the net foreign asset position as a share of GDP were tempered by high nominal growth in some debtor countries and weak growth in creditor countries. Overall, revaluations and other adjustments also had a substantial impact on the net external position of euro area countries (Lane, forthcoming). Although it is impossible to disentangle these effects, their combined impact is strongly negative for most euro area countries over the period 2002 to 2007, reflecting the currency mismatch of euro area countries' positions combined with the weakening of the dollar.

\section{External balances have been driven by internal economic and financial imbalances}

The scale of the current account imbalances and the accumulated net foreign asset and liability positions in some euro area countries raises questions about whether such large and unprecedented developments can be justified by underlying economic needs. In theory, current account deficits and surpluses and international saving and borrowing are an important mechanism for open economies to accumulate wealth or borrow, and to engage in international risk-sharing. To the extent that these positions reflect preferences, technology and initial wealth, they are part of the gains from international trade and finance. Indeed, facilitating such movements of capital by removing nominal exchange rate risks was one of the motivations for monetary union. While long-term solvency implies that countries cannot continuously increase their indebtedness faster than income, some foreign borrowing may be sustainable to finance productive investment and to smooth consumption. For mature economies with ageing populations, building up foreign assets may be an effective way of funding future consumption.

\section{Fundamentals only explain part of external imbalances in the euro area}

International evidence confirms that current account positions are in part determined by fundamental economic factors that underlie relative consumption and investment across countries. Differences in income levels, GDP growth, real interest rates and demographics play an important role (Chinn and Prasad, 2003). Increasing financial market integration has eased constraints on international saving and borrowing and led to a trend widening in the dispersion of current account positions (Faruqee and Lee, 2009). Other observed but less deep economic factors such as nominal rigidities, the fiscal policy stance and the trend level of unemployment also play a role (Cheung et al., 2010). In principle, monetary union would have been expected to reinforce the role of fundamentals for euro area countries and this has been borne out by experience (EC, 2009).

For the euro area in recent years, these fundamental factors do appear to explain a substantial part of the current account imbalances, based on empirical analysis for OECD countries using time-averaged panel econometric techniques (Barnes et al., forthcoming). The results in this study are broadly in line with earlier studies of the international evidence, as cited above. The analysis suggests that demographic factors played a small role in most cases. Germany's demographic position would have been expected to generate a substantial surplus, while a country with a relatively young population such as Ireland would have been expected to have run a deficit (Figure 4). ${ }^{4}$ Income and

4. The current age-dependency ratio boosts current consumption relative to income, while future increases in the age-dependency ratio increased current saving. 
growth differentials also had an impact on the current account, reflecting the flow of capital to low-income high-growth countries, but these effects were relatively small. The initial net foreign asset position had a large impact on imbalances over the period 2002 to 2007. Other factors also have an identifiable role in determining the current account, even if they are not deep economic fundamentals and may even reflect economic excesses. In particular, the budget deficits in Greece and Portugal made significant contributions to their weak external positions. ${ }^{5}$ Strong housing investment, associated with unsustainable property booms, account for large contributions to the current account deficits of Ireland and Spain.

Figure 4. Determinants of the current account balance

Contributions to current account balances over the period 2004 to 2008

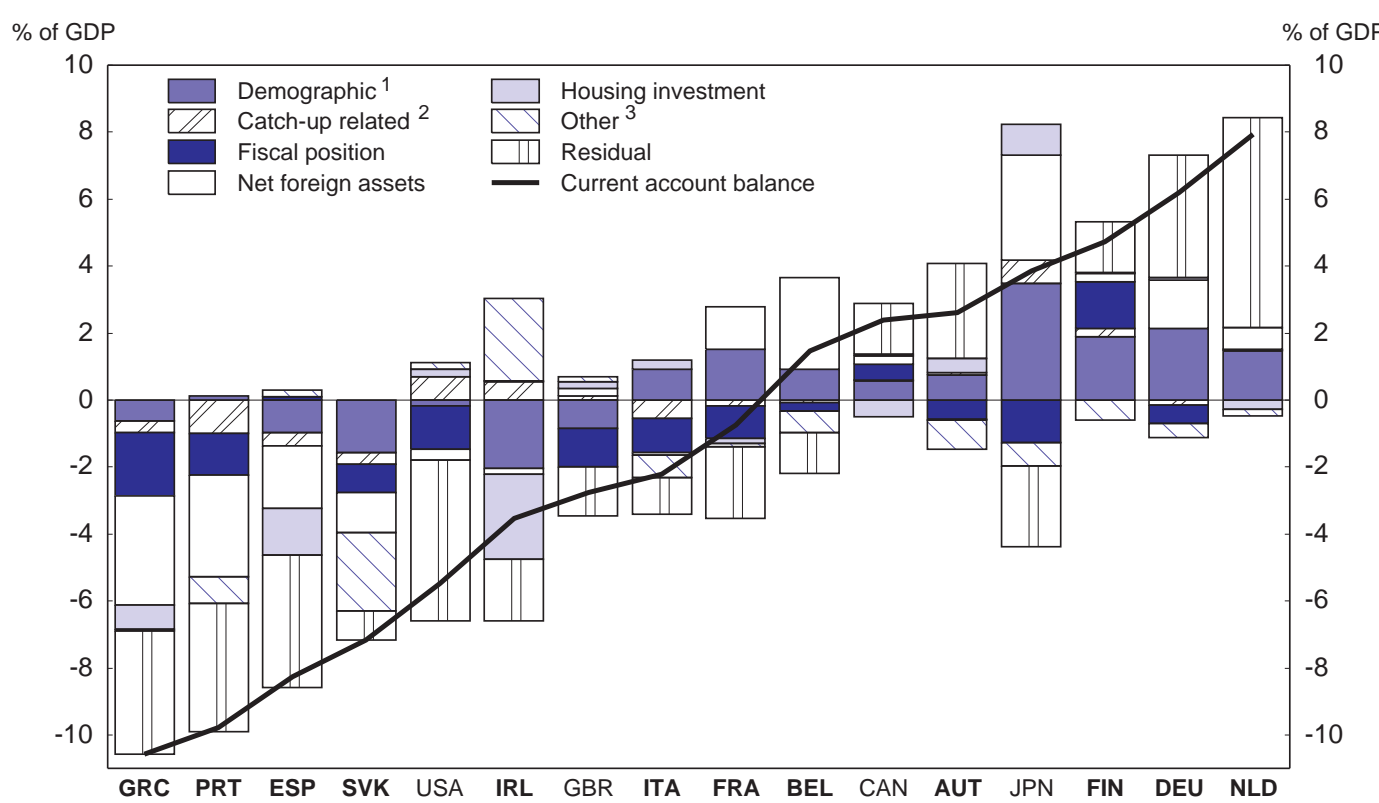

1. Sum of contributions of youth dependency, old-age dependency and expected old-age dependency.

2. Sum of contributions of the level of GDP per capita and GDP growth.

3. Sum of contributions of the real interest rate and other factors.

Source: Barnes, S., J. Lawson and A. Radziwill (forthcoming), "Current Account Imbalances in the Euro Area: A Comparative Perspective", OECD Economics Department Working Papers, OECD, Paris.

Nevertheless, the scale of imbalances over the period in both euro area and other OECD economies cannot be fully explained by historical relationships. While observed factors and historical relationships typically explain the sign of the imbalance, they tend to underestimate the size. Between 2004 and 2008, both the large current account surpluses of Germany and the Netherlands, and the major deficits in Greece, Portugal and Spain, have greater unexplained components in this model than for other euro area countries. Notably, there is also a large unexplained component to the US current account deficit. The unexplained component of current account balances for the most recent period is noticeably larger than for earlier periods. ${ }^{6}$ While the larger residuals cannot by definition be explained within the model, one explanation could be stronger financial market integration. However, the broadening dispersion of current account positions internationally during this period appears to be "well ahead of the underlying dispersion trends" (Faruqee and Lee, 2009).

5. The fiscal balance is typically positively correlated to the current account balance but the effect is much less than one-for-one.

6. This is not the case for Finland. 
This phenomenon is similar across both euro area and other OECD countries. It is consistent with evidence that the strong global credit cycle and global savings and investment trends over this period exaggerated underlying imbalances. Furthermore, the global credit cycle may have distorted some of the fundamental factors treated as exogenous in the analysis, such as growth differentials and real interest rates. Given the unusually large unexplained component of recent imbalances and the explanatory role of factors such as fiscal policy and housing booms, current account imbalances in some euro area countries as elsewhere would appear to have gone beyond what can be explained by fundamentals.

\section{Imbalances arose from diverging economic pressures and domestic imbalances}

Euro area countries were exposed to a wide range of diverging underlying economic pressures over the past decade. The imperfect economic integration of euro area countries and structural rigidities, combined with these diverging forces, required strong economic, macroprudential and fiscal management at the national level in line with the requirements of a shared currency and the associated absence of country-specific monetary policy. The external account ended up playing an important role in absorbing differences in nominal demand across countries, leading to large, persistent and sometimes excessive imbalances (Box 1). For many euro area countries, there was a close relationship between internal and external balances during the most recent upswing (Figure 5). Countries with above-average growth such as Greece, Ireland and Spain suffered from some degree of domestic overheating, leading to current account deficits. Rampant private demand in many cases, driven by low real interest rates and strong credit growth, appears to be the main explanation for the strength of domestic absorption, with the exception of Greece where lax fiscal policy played a big role. By contrast, Austria, Belgium, Germany and the Netherlands had growth below the euro area average and also accumulated large current account surpluses. As discussed above, the scale of the external imbalances appears larger than underlying economic developments can explain. Developments in some other countries were more idiosyncratic. Italy and Portugal experienced very low growth, weak competitiveness and current account deficits. In the case of Portugal, this weak position is partly the result of over-reliance on consumption and housing activity in the early 2000s of similar nature to that seen more recently in other deficit countries (OECD, 2010c). Weak subsequent labour productivity gains coupled with insufficient wage moderation have since frustrated the rebalancing of the economy and caused the large current account deficit to be sustained. In the case of Italy, weak economic performance and the deterioration in competitiveness were the result of wage growth running ahead of low productivity gains, resulting from structural problems and the reorganisation of industrial production (OECD, 2009a). As anticipated by the Optimal Currency Area literature, imbalances have tended to be particularly large in those countries experiencing the most asymmetric shocks relative to the euro area average, as well as those that were the least integrated with other euro area economies and had high structural barriers to economic adjustment. 
Figure 5. Growth and imbalances in the euro area

Annual average rates, 2002-07

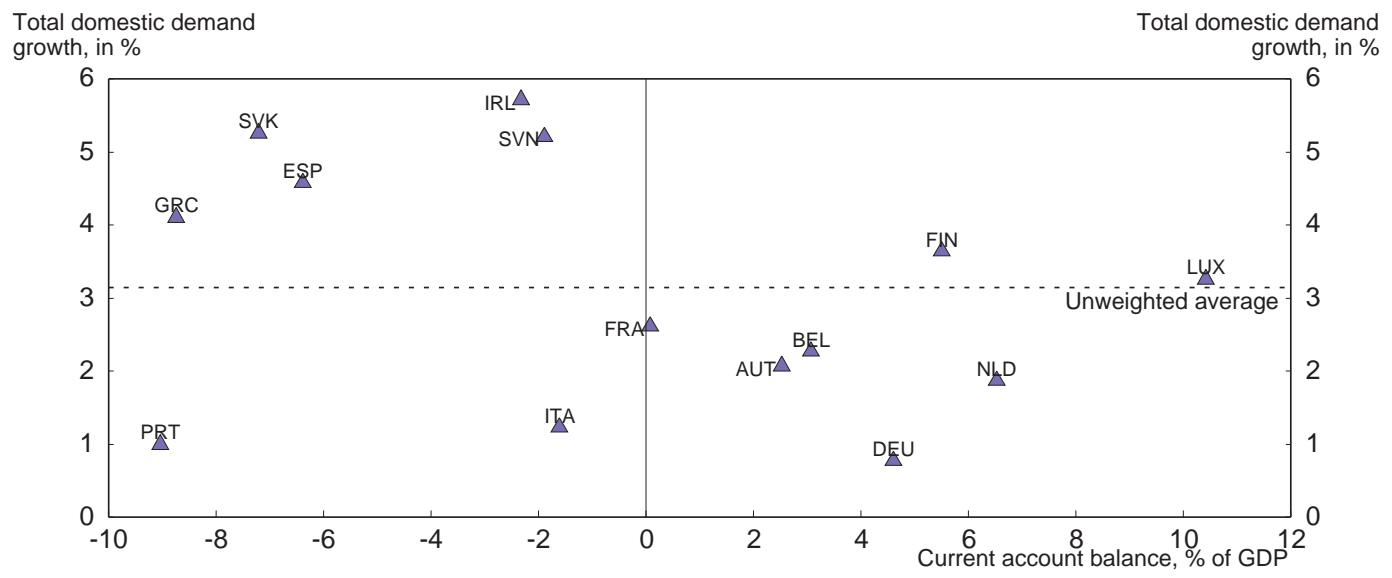

Source: OECD, OECD Economic Outlook Database.

\section{Box 1. Economic stabilisation in a monetary union}

The objective of macroeconomic policy should be to achieve an efficient and sustainable growth. Efficiency in this sense occurs where marginal costs of production are minimised over time and consumption follows intertemporal preferences. This requires balancing total demand and supply in the domestic economy, internal balance, and making sure that the current account position is consistent with the efficient level of external capital accumulation or reduction, external balance (Williamson, 1983). If the efficient net external position is zero, this implies that domestic absorption is equal to potential output.

\section{Economic adjustment to country-specific shocks}

Even in a simple stylised framework, the dynamics of economic adjustment to country-specific shocks are complicated for small open economies in a monetary union. Under the assumptions of the standard Mundell-Fleming model with a fixed nominal exchange rate and perfect capital mobility, a shock to nominal demand in one country has a large effective impact on aggregate demand because the supply of money is perfectly elastic so there is no crowding out from higher interest rates (Flemming, 1962; Mundell, 1962). Monetary conditions are perfectly accommodating.

Shocks to nominal demand, however, create inflationary pressures in the domestic economy. Under the assumption that tradeable goods prices are fixed in international markets, only non-tradeable goods prices increase in response to a positive shock to demand. This raises the overall price level.

The change in the price of non-tradeables relative to tradeable goods leads to a loss of competitiveness. This causes expenditure to shift towards tradeable goods, while stronger demand for labour in the non-tradeable goods sector drives up economy-wide wages and labour and production switch to non-tradeable goods. The current account balance deteriorates. This competitiveness channel contributes to the stabilisation of domestic economy under standard assumptions by accommodating shocks to demand through net exports and thereby attenuating the inflationary consequences.

Given that nominal interest rates are fixed for the euro area, the real interest rate channel acts as an amplifying and destabilising force. A negative shock to domestic demand, for example, will tend to reduce the price level and increase competitiveness. As prices fall, the real interest rate rises, further dampening domestic demand in the short run. Furthermore, with nominal price rigidities, optimal monetary policy would be set partly to offset the combined impact of the initial shock and the rigidities (Galí and Gertler, 1999) so there is a further cost in real interest rates not being able to follow optimal policy, as for example suggested by a standard Taylor rule. This cost will be higher if nominal rigidities are stronger.

These adjustment channels taken together imply that a positive nominal demand shock leads to a state where internal balance is restored through changes in the price of non-tradeable goods that alter domestic consumer prices and shift the external balance of the economy. A corollary of this situation is that real consumption can be increased by domestic expansion for a time. However, this situation is inefficient as marginal costs in the economy are moved away from their efficient level and changes in the net asset position may not reflect underlying preferences, wealth and technology. 
The equilibrating mechanisms to achieve external balance, by contrast, are more subtle with current account balance being restored by the need to repay borrowing or run down savings to meet the long-run solvency constraint. This may occur gradually or through dramatic reassessments by lenders of the prospects of different economies. Even with price flexibility, shocks may result in persistent deviations of external balance from its efficient level and the forces to balance the current account may be weak for long periods. The failure to respect this long-run constraint, either on the part of borrowers or lenders, may contribute to prolonging the adjustment period.

\section{Financial accelerator effects add to economic instability}

Low real interest rates can aggravate imbalances while the economy is strong, as they can trigger domestic credit cycles and financial accelerator effects. There are two main conventional channels for financial accelerator effects (Bernanke and Gilchrist, 1995): the balance sheet channel, whereby the value of collateral or availability of cash flow determine how far potential borrowers are able to commit to repay loans, and the bank lending channel, whereby the supply of bank credit is affected by the strength of banks' balance sheets. The balance sheet channel has a strong country-specific effect because the value of property-related collateral, which is particularly important for household and commercial property lending, depends on local property prices: a credit-induced rise in house prices will tend to increase the value of houses in the same locality. The country-specific effect of a given interest shock also depends on structural features of the national credit market (Catte et al., 2004). Risk appetite may also be higher when real interest rates are low: risk appetite is related to the temporal marginal rate of substitution (Lucas, 1978). Given that the real interest rate inside the monetary union varies because consumers in different countries face different non-tradeable goods price developments, risk preferences will also vary. In addition, there may be irrational exuberance in countries where the economy has been booming.

The diverging economic pressures have had a number of sources. Greece, Ireland and Spain have over recent decades been experiencing a period of economic catch-up from low levels of income compared with other euro area countries, which creates a number of tensions. A similar process took place in Portugal, although this stalled over the past decade and the correction has been prolonged. Firstly, productivity growth in some catch-up countries, notably Ireland occurred at a faster pace in the tradeable goods sector, giving rise to inflation as resources were reallocated from the non-tradeable goods sector in line with the Balassa-Samuelson effect. However, this effect is not systematic across countries. $^{7}$ While such inflation is consistent with equilibrium adjustment, the resulting lower real interest rates has a destabilising effect. Secondly, a rapidly changing economy can be difficult to stabilise. When future productivity gains are anticipated, current consumption and investment will be high relative to the supply capacity of the economy, which can cause demand and prices of non-tradable goods to run ahead of actual increases in productivity in the tradeable sector, thereby crowding out some of the gains in export performance (Corden and Neary, 1982). Furthermore, the ending of the catch-up phase can also be difficult to identify contemporaneously, particularly when domestic demand is booming and the overall growth of the economy remains strong. Comparing the upswing from 2002 to 2008 with the period from 1994 to 2000 in Spain, for instance, suggests this type of over-shooting, as domestic demand accelerated slightly to an annual average of $4.4 \%$, while export growth dropped from around $11 \%$ in the earlier period to just over $4 \%$. In Ireland, economic performance weakened on most measures between these periods as activity also became much more domestically focussed (OECD, 2009b). This pattern of weakening underlying economic performance, combined with strong real estate investment and borrowing, has parallels to the "bubble economy" of Japan in the late 1980s (Hayashi and Prescott, 2002). Thus borrowing by countries such as Greece, Ireland, Portugal and Spain took place against strong expectations of growth that have not been sustained.

Financial liberalisation and gains in monetary policy credibility with the creation of monetary union, which combined to reduce the cost of borrowing, were particularly large for the group of

7. The Balassa-Samuelson effect in the case of Ireland is strong and positive on inflation but it is relatively small in some countries that experienced relatively low inflation (Égert, 2010). However, the effect is not systematic across countries (see also EC, 2009). 
countries that subsequently had large deficits. During the five years leading up to monetary union, the nominal long-term interest fell by more than 5 percentage points in Italy, Portugal and Spain, compared with an average of around 3percentage points for the euro area as a whole. The fall in nominal borrowing costs reflects a combination of lower real interest rates, lower expected inflation and a reduction in risk premia. Lower inflation may further ease credit constraints early in the life of a loan where there is front-loading of real repayments. These developments were matched by a widespread convergence in market interest rates across countries (ECB, 2010). For some countries, this implied a reduction in credit spreads that further added to relatively large falls in real interest rates. At the same time, the development of the single European capital market contributed to expanding the availability of capital for euro area countries (OECD, 2009c). Small countries may face a very high elasticity of supply of credit within a larger currency union once currency risk is removed and given that increasing exposure to their country-specific risk does not have a large impact on overall portfolios (Barnes, Lane and Radziwill, forthcoming). These capital flows may be overwhelming for small and less-developed financial systems (Portes, 2001). Monetary union appears to have increased the elasticity of net capital flows to income differences between euro area countries compared to the past with no effect on capital flows from other countries (Schmitz and von Hagen, 2007).

Strongly divergent economic pressures also contributed to the large surpluses in some countries. Although the size of the German economy implies that it has a large weight in the euro area economy (it accounts for around a quarter of euro area GDP), ECB policy will not necessarily fully stabilise domestic developments there. During the upswing, Germany experienced an idiosyncratic sequence of economic developments at the opposite end of the range from Greece, Ireland, Portugal and Spain. Following the economic downturn in 2000 , the early phase of the recovery was heavily influenced by continued adjustment to the consequences of German reunification: lost competitiveness needed to be regained and the unwinding of the construction boom continued to weigh on investment (OECD, 2010b). Production was restructured and in part relocated through strong FDI outflows to Central and Eastern Europe. A high priority was given to structural reform with a number of significant labour market reforms and an overhaul of the pension system, which lowered replacement rates and set out a future increase of the retirement age to 67. This may have increased household savings. Uniquely among euro area countries, house prices in Germany fell over this period. At the same time, there was marked pay restraint leading to a reduction in unit labour costs. These German-specific factors led domestic demand to expand at an annual average rate of just $0.3 \%$ on average over the period 2002 to 2007 (compared with $1.8 \%$ for the euro area), while exports increased at an average annual pace of $7.5 \%$. In the Netherlands, meanwhile, a sharp increase in pension contribution rates following the bursting of the "dot com" bubble considerably weakened consumption, while fiscal consolidation efforts also contributed to boosting national saving.

\section{Fiscal policy failed to prevent or even contributed to the build-up of imbalances}

The role of fiscal policy in imbalances varies across countries. Cross-country experience suggests that the relationship between current account and fiscal balances is relatively weak on average. Based on a large sample and a wide variety of techniques, econometric evidence suggests that a strengthening of the fiscal balance of 1 percentage point of GDP leads to an increase in the current account of around 0.2 to 0.3 percentage points of GDP (Abbas et al., 2010). ${ }^{8}$ The effects may be larger than average if the change in the fiscal position is viewed as permanent, particularly in the longer run and for small economies (Kumhof and Laxton, 2009). During the upswing, Ireland and Spain ran

8. This effect is in line with estimates reported in Barnes et al. (forthcoming) for OECD and euro area countries, along with previous studies in the current account literature. 
small budget deficits and eventually surpluses. While these were insufficiently large to counteract private sector imbalances and were boosted by buoyant tax receipts linked to the financial cycle and housing, the fiscal position did not actively contribute to their current account deficits and their government debt-to-GDP ratio declined substantially. By contrast, Greece ran deficits averaging 5.4\% of GDP during the period from 2002 to 2007, while deficits averaged well over 3\% of GDP in Portugal. These can account for a large share of the overall current account deficit, although the overall impact is likely to have been lower in line with the offsetting effects implied by the semi-elasticities given above. During this period, Germany and the Netherlands ran budget deficits but these were more than offset by strong private saving. ${ }^{9}$ Fiscal tightening during this period, while contributing to medium-term fiscal stabilisation, accounted for part of the increase in the national saving rate.

\section{Stabilisation of shocks was ineffective}

Diverging pressures on nominal demand shocks and varying underlying economic developments, combined with structural rigidities, made economic and financial stabilisation hard to achieve. As variations in nominal demand translated into inflation, real interest rates played a de-stabilising role. During the upswing, ex post real interest rates were on average negative in high growth countries, such as Greece, Ireland and Spain, and barely positive in Italy and Portugal. By contrast, real interest rates averaged $1.8 \%$ in Finland, $1.5 \%$ in Germany and around 1\% in Austria, France, Luxembourg and the Netherlands. While it is inherently difficult to assess real ex ante interest rates as the relevant inflation expectations are hard to observe, the persistence of inflation differentials over this period was marked and ex post real rates may provide some guidance about ex ante rates. In addition, survey balances of consumer expectations from the EC Inflation Perceptions survey broadly follow outturns and were highest in countries such as Greece, Italy and Spain. There is also a close correlation between current account positions and the cumulated deviation of real interest rates from a simple Taylor rule (Figure 6). ${ }^{10}$ This means that the Taylor principle for economic stability, whereby real interest rates rise sufficiently to dampen inflation pressures, has not been met. Although similar tensions are likely to arise within countries and in other currency unions, the extent of these differentials in the euro area may have been relatively large. Inflation differentials across urban areas in the United States are much lower than across euro area countries and, as they are less persistent, their impact on economic behaviour is likely to be more transitory and limited (Box 2).

9. $\quad$ Except for 2007 when Germany ran a surplus.

10. A similar relationship holds for real interest rates. The simple Taylor rule used in Figure 2.6 assumes a common neutral interest rate and inflation rate-target and therefore ignores potentially important differences across countries. Furthermore, it depends on highly uncertain estimates of the output gap. 
Figure 6. External balances, interest rate gaps and competitiveness Annual average rates, 2002-07
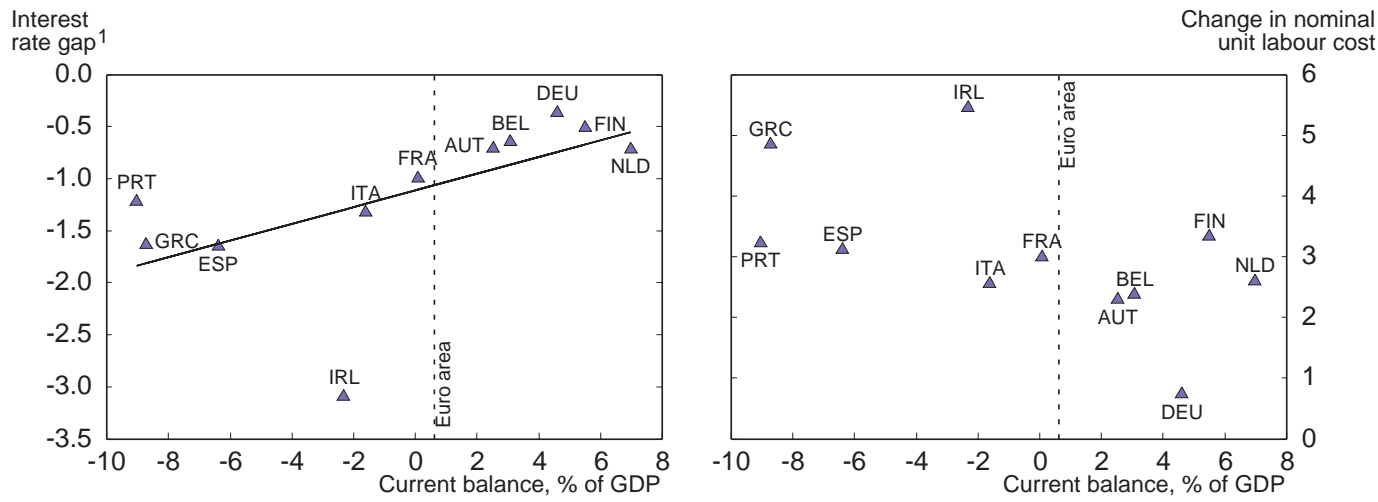

1. Interest rate gap defined as the deviation of short-term interest rates from a simple Taylor rule with coefficients of 0.5 on the output and inflation gaps, a core HICP inflation target of $1.9 \%$ and neutral real interest rate of $2.1 \%$.

Source: OECD, OECD Economic Outlook Database.

\section{Box 2. Inflation differentials in the United States}

The problems of ineffective macroeconomic stabilisation inside the euro area should in principle also be at work in other currency unions. The United States has functioned as a currency union in various forms since 1789 and provides the most obvious point of comparison for the euro area in economic size and population. Have inflation differentials in the United States played a similar role to those within the euro area?

It is difficult to make an exact comparison. The US consumer price index (CPI) and the EU harmonised index of consumer prices are constructed in different ways and measure somewhat different concepts of consumer prices. Also, there are no state-level data for the United States and the most comparable data cover 14 urban areas only. Finally, it is difficult to compare the aggregate variability that would be expected all other things being equal between 13 countries and 14 urban areas.

However, subject to these caveats, it is tempting to conclude based on these data, that the variability is relatively similar within the euro area as across US urban areas (Figure 2.7, left panel). However, the US CPI series includes an important "shelter" component which closely reflects local property prices, while the HICP excludes costs associated with owner occupation of housing. Given the wide and sizeable variation in housing prices across US urban areas in recent years, there may be an upwards bias in the variation of US urban area inflation relative to the euro area. Comparing US urban-area level CPI inflation excluding housing with inflation in the euro area based on a derived measure excluding rents, the dispersion of these measures of inflation across US urban areas is markedly lower than between euro area economies over the same period (Figure 7, right panel).

\section{Figure 7. Inflation differentials across US urban areas and EU states ${ }^{1}$} Standard deviation across units
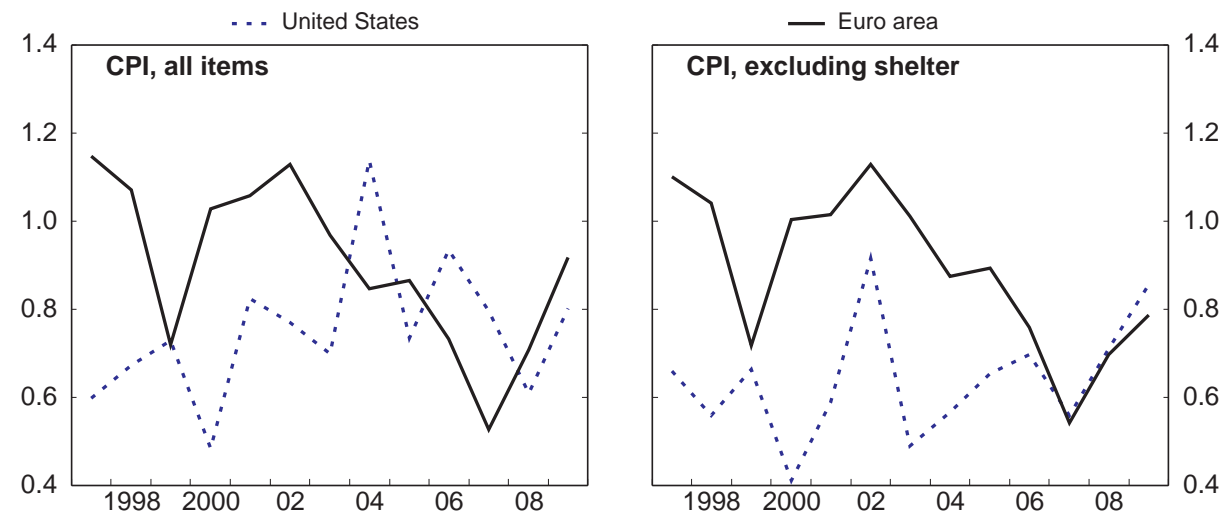

1. CPI for the United States and HICP for the euro area.

Source: Eurostat and US Bureau of Labor Statistics. 


\begin{abstract}
The destabilising effect of inflation through lower real interest rates depends not only on the dispersion of inflation across local economies but also the persistence of these differentials. Short-term deviations from area-wide inflation that rapidly correct are likely to have little impact on economic behaviour, while persistent and predictable differentials are more likely to influence borrowing and saving decisions. Based on inflation excluding shelter, the persistence of annual inflation rates across US urban areas is much lower than for euro area countries. The standard deviation of the change in the price level with the euro area average over the period 2002 to 2007 is $4.4 \%$, while it was just $0.4 \%$ for US urban areas.
\end{abstract}

The apparently lower and less persistent variability of inflation across US urban areas suggests that the pressures of monetary union there could be lower than in the euro area. For example, there is no clear relationship between the implied real interest rate (based on CPI excluding shelter) and the change in house prices during the economic upswing, by contrast with the clear pattern in the euro area. This transatlantic difference may reflect different sizes or patterns of shocks, or greater price flexibility across US urban areas. There are also important differences in the structure of the currency union, including the large role of the federal government in the United States, greater structural rigidity than in some euro area countries and a much more integrated financial and banking system, including the system of federal deposit insurance.

The variation in the strength of domestic demand contributed to divergent trends in competitiveness. Real effective exchange rates (on a GDP deflator basis) in the euro area and in almost all countries appreciated over the period 2002 to 2007 with the notable exceptions of Germany, whose real effective exchange rate was broadly unchanged, and Finland. The appreciation was particularly marked in Spain (15\%), Ireland (13.5\%) and Greece (13\%). Broadly similar patterns hold for other measures of price competitiveness and for both intra-euro or wider effective exchange rate measures (EC, 2010a). ${ }^{11}$ Consistent with the underlying theory, price increases were particularly marked in the non-traded services sectors of overheating economies and especially in construction (Égert and Kierzenkowski, 2010). While some of these movements may have been equilibrium adjustments in prices, others most likely reflect unsustainably strong aggregate demand.

In some cases, underlying productivity and structural developments have played a part in determining overall imbalances, in particular where wage and price developments have been out of balance with productivity growth. In particular, Italy suffered a marked decline in export performance for structural reasons that was not offset by a reduction in prices. The weakness of the Portuguese economy after the boom of the late 1990s is likely to have been attenuated if competitiveness had been restored, thereby rebalancing the economy from the consumption to the production of export goods. These problems have often been the result of structural policy settings, such as restrictive product market regulation and heavy employment protection legislation. These have held back growth and for some countries slowed adjustment to shocks. The low underlying productivity growth of Spain was a drag on competitiveness, combined with strong price increases. Indicators of the market orientation of product and labour market regulations suggest that Greece and Portugal lag well behind OECD averages and suggest that their economies are relatively inflexible with scope to reform remaining in Spain, despite reforms over the past decade (OECD, 2010d). In Germany, structural barriers to the development of the non-tradeable sector reduced investment and biased activity towards the export sector (OECD, 2010b).

Stabilisation, particularly of the external balance, was complicated by a number of other factors during the upswing. Firstly, while prices increased and the real exchange rate appreciated in overheating economies, the effect was dampened by large net inflows of migrants (Box 3). This made it difficult to assess how far demand was from a sustainable level. Secondly, price rigidities and persistence tend to slow adjustment through prices and the underlying pressures can be difficult to detect. It is unclear how much of the price persistence was intrinsic and how far it reflected a

11. Alternative measures include the consumption deflator-based real exchange rate, unit labour costs and export price. 
correlated series of shocks or the strength of the long credit cycle. The experience of Ireland is notable: inflation was persistently above the euro area average for many years prior to the crisis but the price level has since drastically fallen. Thirdly, capital markets did not adequately price the risk associated with economic and financial imbalances in individual euro area countries, and credit conditions were not tightened in countries that were clearly overheating prior to the crisis. The recent experience both in the euro area and elsewhere has differed from the past where current account reversals typically occurred when deficits reached 5\% of GDP (Freund and Warnock, 2007), perhaps as the result of financial liberalisation or the financial boom during the "great moderation". This experience also contrasts with earlier experience under the Exchange Rate Mechanism (ERM), where relatively high domestic inflation and losses of competitiveness would result in speculative pressures on the exchange rate peg, leading to changes in nominal exchange rates. Within a monetary union, the potentially important signals and market discipline played by the nominal exchange rate were lost, while credit spreads did not respond to large imbalances until recently.

\section{Box 3. Economic adjustment through migration to overheating economies}

Movements of factors of production in open economies play an important economic role and can have a stabilising effect in monetary unions, helping to offset asymmetric shocks. While labour mobility in Europe is generally much lower than in the United States, the high openness of euro area countries does lead to flows of migrants from the EU and other countries. Labour mobility is facilitated by the Single Market, further encouraged by EU enlargement, as well as links with former colonies.

The pull and push factors leading to migration are complicated. However, growth and imbalances in the domestic economy appear to have been a driver for migration flows over recent years (Figure 8). Based on the net annual flow of non-national migrants per thousand of the population, there was little variation across countries in the average flow from the mid-1980s to 2001. There was also little relationship to growth. By contrast, net migration flows were much stronger in some cases over the period from 2002 to 2007. Ireland and Spain had annual average migration of over $1 \%$ of the existing population in these years. Although the relationship is not close, migration does appear to have been related to growth and to current account imbalances: some of the strong domestic demand was absorbed by migration. It is notable that this additional labour appears to have been heavily employed in the non-tradeable sectors, such as construction or services, rather than in boosting labour supply in the traded goods sector. Since the peak of the cycle, net migration flows have slowed and reversed in the overheating economies.

Figure 8. Net foreign migrant flows and demand
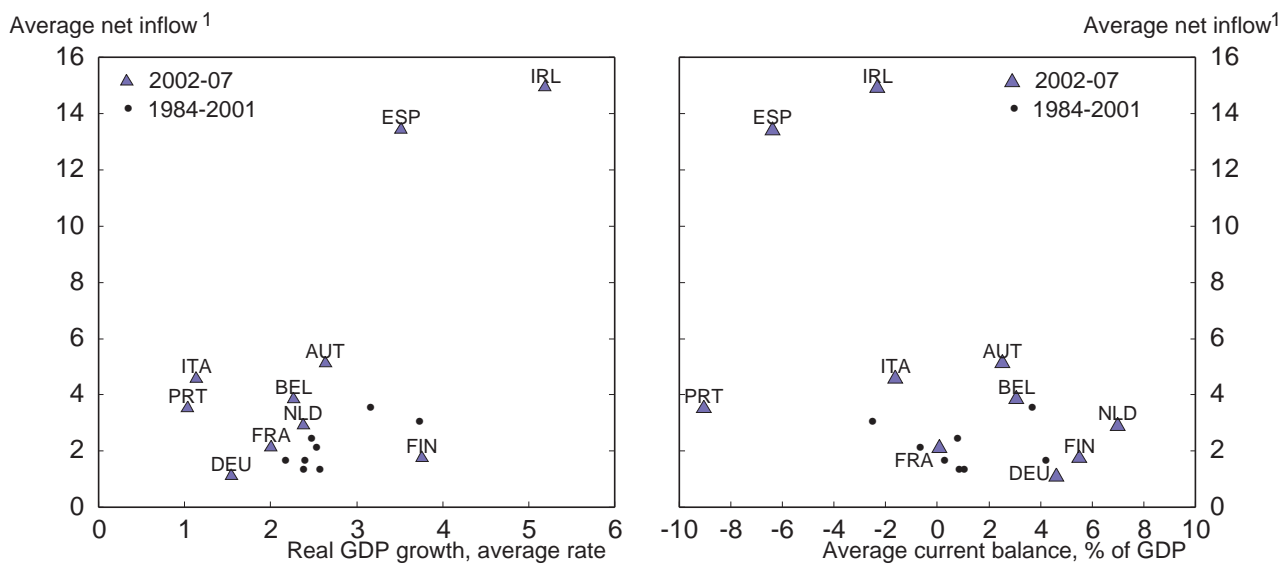

1. Net inflow of foreign population per thousand inhabitants.

Source: OECD, OECD Economic Outlook and International Migration Databases.

High migration flows in Ireland and Spain accounted for a large and increasing share of the overall increase in employment during the most recent part of the economic upswing. In Spain, the share of non-nationals in the labour force went from $4 \%$ in 2001 to reach $13 \%$ by 2007 (Figure 9). There were similar developments in Ireland where foreign workers came to account for around $10 \%$ of the workforce. There was also a rise in net inflows of migrants in some countries such as Italy, albeit to a much lesser extent. 
The substantial net flows of migrant workers into economies with strong domestic demand during the upswing are likely to have helped to accommodate strong growth, reducing the responsiveness of wages and prices to domestic demand. While this helped to accommodate inflation pressures, this would tend to increase the current account deficit through higher domestic consumption and increased workers' remittances. The temporary flatness of the supply curve induced by migrant flows complicates the assessment of sustainable levels of output and the setting of economic policy, both through making it more complicated to assess inflationary pressures and through uncertainty about how permanent migration will be.

Figure 9. Employment growth in Spain

Contributions to annual growth rate, per cent

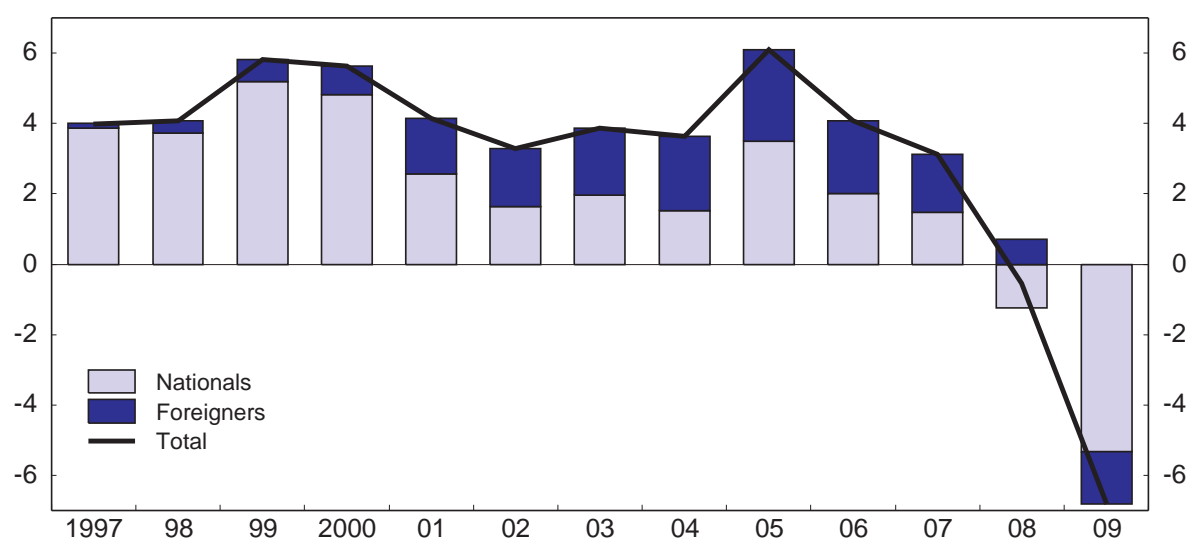

Source: Eurostat.

\section{Domestic savings and investment imbalances led to large changes in balance sheets}

Demand imbalances and destabilising real interest rates, together with some local factors, drove persistent borrowing and saving in euro area countries. In particular, high net saving in countries with weak growth was associated with current account surpluses, while low saving in overheating economies contributed to deficits (Figure 10). Government deficits accounted for some of the weakness in current account positions for Greece, France, Ireland and Italy, and for a significant part of the surplus in Finland, although the size of these fiscal positions overstates their economic impact on the external balance. The non-financial business sector has played a large role in overall saving and borrowing with substantial net borrowing in France, Italy and Spain and strong net lending in Finland and the Netherlands. Overall, the picture across countries is complicated, reflecting the wide variety of forces acting on each economy. However, the relationship between household saving and external balance is more systematic. This is consistent with the underlying economic adjustment mechanisms. The real interest rate channel should have the strongest impact on the household sector, through its impact on consumption of non-tradeable goods, rather than the business sector which is likely to be more sensitive to international conditions. 
Figure 10. Net saving and investment balance and the current account

Percent of GDP, average 2002-07

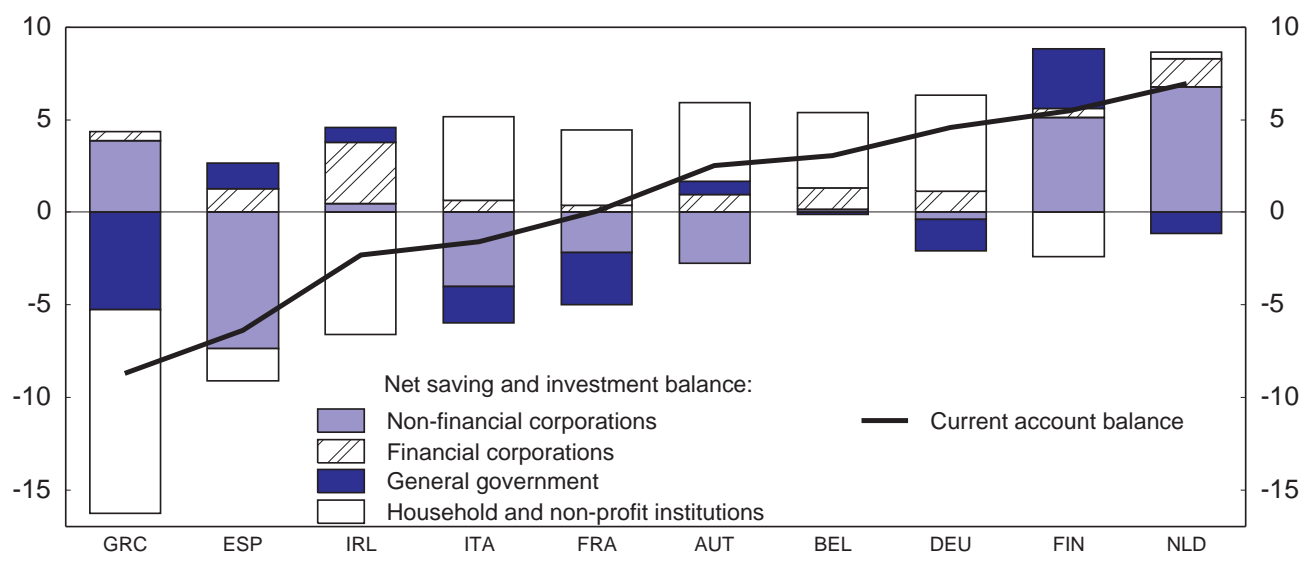

Source: OECD, National Accounts and OECD Economic Outlook Databases.

These large and persistent savings and investment imbalances led to large changes in net financial wealth of economic sectors in some countries (Table A.1). The household sectors in Ireland and Spain reduced their net financial wealth by around 25 percentage points of GDP from 2002 to 2007, through heavy borrowing, with their net financial position relative to income reaching a level below that in many other euro area countries. Although the decline in financial balances was associated with the rising value of housing assets, much of the increase in house prices proved to be unsustainable and has been reversed subsequently. By contrast, German households increased their net financial wealth by almost 30 percentage points of GDP over the same period, while there were increases of about half that size in Austria and France. For non-financial corporations, the net financial asset position of Spanish corporations declined by around 60 percentage points of GDP due to low saving and high investment. By contrast, companies resident in the Netherlands increased their financial position to a net balance in excess of $15 \%$ of GDP over the period. High profits, low dividends payouts and relatively weak investment in Germany had a similar effect (OECD, 2010b). Apart from determining net financial wealth, real interest rates also led to changes in the leverage of different sectors. These effects appear stronger and more systematic for households: the ratio of household debt to financial assets rose considerably in Greece, Ireland and Spain over the period from 2002 to 2007, while it actually fell in Austria and Germany.

\section{Housing booms and credit cycles aggravated imbalances}

Low real interest rates sparked housing and credit cycles in some countries (Ahrend, 2010). Changes in non-tradeable goods prices have a strong impact on the housing market: as it is essentially a non-tradeable investment good, demand for housing is particularly sensitive to real interest rate developments (EC, 2006). House prices in Spain increased by close to $80 \%$ in nominal terms from 2002 to 2007, with prices increasing by around 70\% in France and 45\% in Ireland. The share of housing investment in Ireland peaked at over 13\% of GDP and around 9\% in Greece and Spain. Although the stock of dwellings per capita in these countries was well below OECD norms in the 1990 s and population growth rate was relatively fast, the pace of housing construction was nevertheless spectacular. These underlying dynamics, combined with very low or negative real interest rates, created highly favourable conditions for the emergence of housing bubbles. The expected increase in prices implied that borrowing to invest in housing appeared profitable irrespective of any actual or imputed rents (Fuentes Castro, 2010). In addition, high construction prices have been an important channel for crowding out exports through pushing up domestic costs (Égert and Kierzenkowski, 2010). The effect of strong domestic demand on housing was further amplified during 
the upswing in Ireland and Spain by large inflows of migrants, further adding to the demand for accommodation. There is close relationship between housing investment and current account deficits (Barnes et al., forthcoming).

The pressures on housing demand were augmented by poorly-designed policies. Firstly, generous taxation of owner-occupied housing distorts incentives towards housing and increases post-tax gains to home owners from rising property prices, while subsidising the rising cost of housing for those looking to buy. There is a close relationship historically between the variability of house prices and tax distortions for euro area countries (Figure 11). These tax distortions amplify the impact of financial liberalisation and of lower unemployment on the house price to income ratio (Andrews et al., forthcoming). Secondly, the impact of changes in demand on house prices is strengthened by a low elasticity of supply of housing in most euro area countries. Although in some cases this is the result of a high density of population, planning practices are relatively restrictive in euro area countries compared with the norm in other OECD countries and obtaining planning permission can be a lengthy process.

Figure 11. House price volatility and the tax treatment of housing

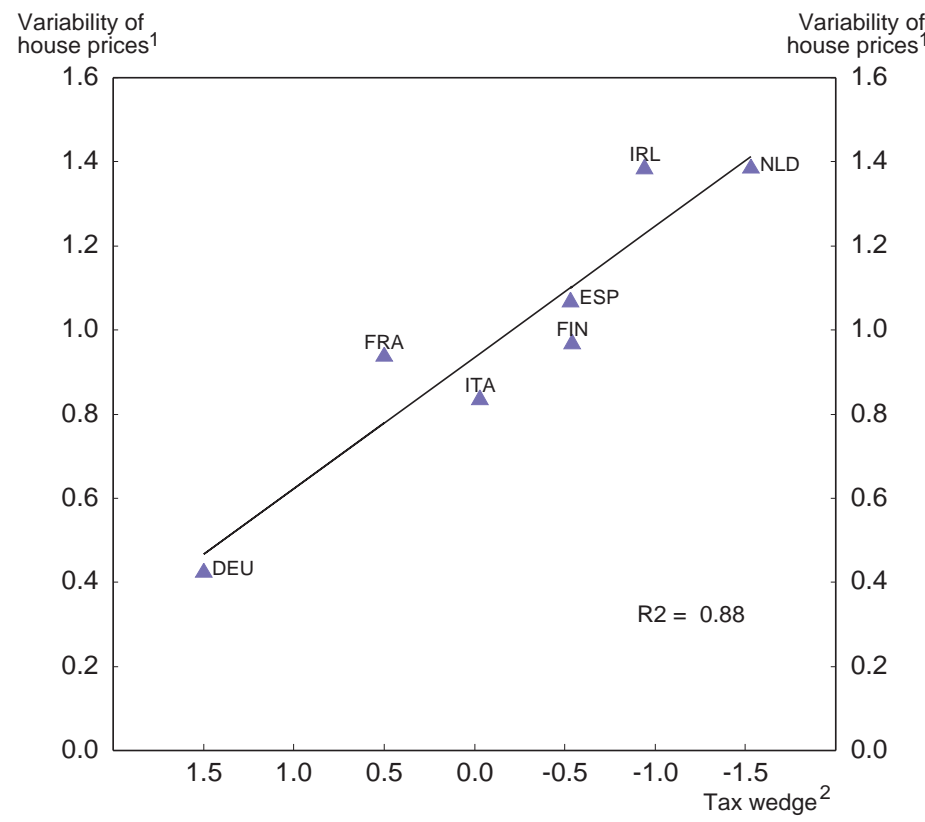

1. Root mean square deviation of real house price from exponential trend, 1970-2009.

2. Difference between after-tax and pre-tax real interest rate on mortgage loans; 1999 tax rules, interest rates and inflation.

Source: Van den Noord, P. (2004), "Tax Incentives and House Price Volatility in the Euro Area: Theory and Evidence", Économie Internationale and OECD calculations.

Strong domestic demand and low real interest rates led to financial accelerator effects that reinforced initial positive demand shocks in some countries experiencing overheating. Loans to the real economy increased at an average rate of around $20 \%$ in Greece, Ireland and Spain over the period 2002 to 2007, compared with no change in Germany and close to 5\% in a number of other surplus countries (Figure 12). Lending was closely associated with external imbalances. These effects partly operated through rising property prices, which appeared to strengthen household balance sheets and provided collateral to finance additional borrowing and lending. The growth of loans for house purchase follows a similar pattern and was also closely associated with deviations of real interest rates from a simple Taylor rule. The partly self-perpetuating effects of the credit cycle may have contributed to the persistence of internal demand pressures and the scale of external imbalances. The rapid growth 
of credit to the non-financial-sector in some countries reflects domestic credit cycles, which were fuelled in part by credit flows from banks with surplus positions in other countries.

Figure 12. Loan growth and imbalances in the euro area Annual average rates, 2002-07
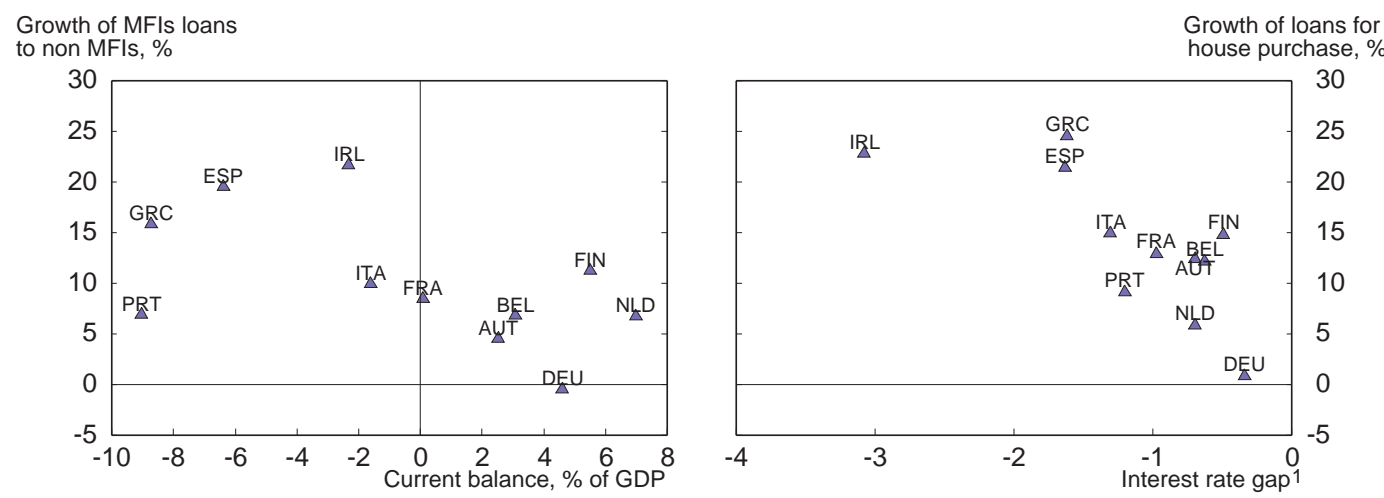

1. Interest rate gap defined as the deviation of short-term interest rates from a simple Taylor rule with coefficients of 0.5 on the output and inflation gaps, a core HICP inflation target of $1.9 \%$ and neutral real interest rate of $2.1 \%$. Source: ECB and OECD, OECD Economic Outlook Database.

Recycling of euro area savings from surplus to deficit countries through the euro area banking systems tended to concentrate risks at the country level. Despite the high level of financial integration at the wholesale level, many aspects of the euro area financial system retain profoundly local characteristics, particularly in terms of retail activity. This led to local concentrations of risk rather than efficient diversification across the euro area. In particular, local banks are largely responsible for intermediating between domestic non-financial borrowers and depositors. These banks then fund or redistribute any imbalances between the two through international market and interbank sources. This may leave local banks carrying much of the risk and can also lead to additional risks relating to maturity mismatch, given the more volatile nature of market funding. It also reinforces domestic credit cycles as financial accelerator effects tend to work in the narrower national market rather than in the large euro area, yielding stronger feedback effects. The absolute size of bank assets in some countries became very large relative to national income, ${ }^{12}$ a development which was exacerbated by the ability to access market funding from other euro area countries. There were strong flows of capital from banks and other financial institutions from countries with sluggish domestic credit growth to overheating credit markets, as the result of the large volume of funds at their disposal and weaknesses in financial oversight. This contributed to a large gap between the growth of domestic loans and deposits in many euro area countries: economies with external surpluses saw deposit growth significantly outstrip loan growth, while deficit countries tended to experience the opposite (Figure 13). In terms of the euro area as a whole, Germany and the Netherlands were significant providers of funds, while France, Italy, Ireland and Spain were the major borrowers. International bank credit flows were often relatively short-term in nature, leading to a risky maturity mismatch in the borrowing countries.

12. See Box 1.1 "How Big is the Irish Banking Sector?" in OECD (2009b). 
Figure 13. Gaps between change in loans and deposits ${ }^{1}$

As a percentage of 2004 GDP

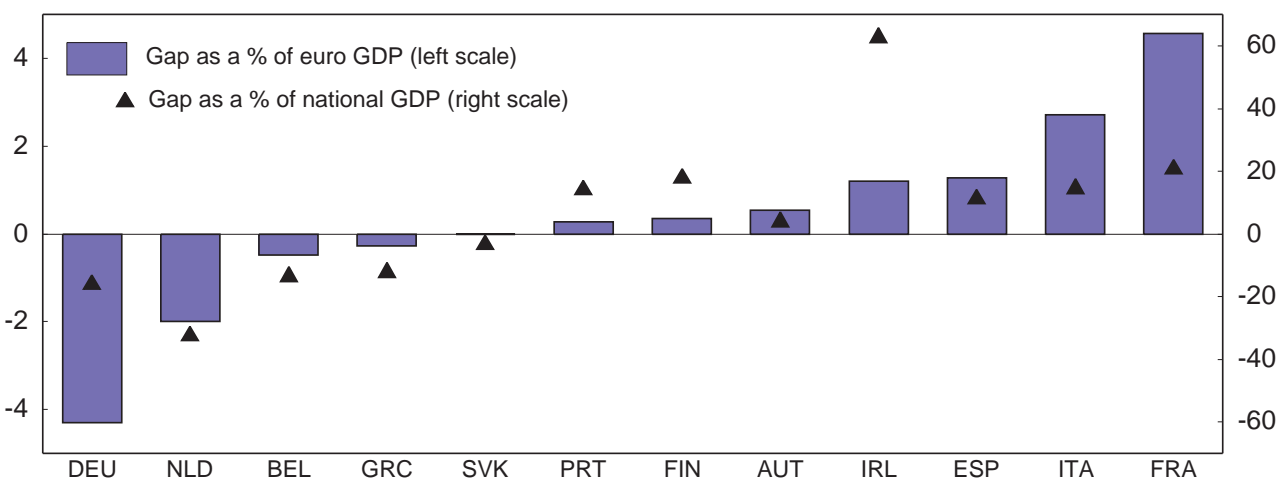

1. Change in loans of credit institutions (Cls) to non-Cls minus change in deposits of Cls from non-Cls between 2004 and 2008.

Source: ECB (2010), Structural indicators for the EU banking sector and OECD, OECD Economic Outlook Database.

Weaknesses in financial regulation and supervision encouraged a significant increase in risk-taking during this period, while regulatory shortcomings in some euro area countries and the lack of effective macroprudential regulation facilitated this risk taking. While Spain took the strongest steps to counter the financial cycle through dynamic provisioning and measures that controlled the use of securitisation, this was insufficient to prevent a strong credit and housing cycle even if these measures appear to have offered some protection to the banking system. Weaknesses in financial regulation in countries without pronounced domestic credit cycles nevertheless added to problems in other countries through financial markets. This was important in countries with weak domestic credit demand, and their banking activity and profits became increasingly reliant on supplying credit abroad.

The transfer of risks and funds increased potential for spillovers between countries and macroeconomic risks in countries experiencing strong and unsustainable inflows of credit. International banking activity can involve the transfers of risks between countries, as well as flows of funding. These are not necessarily identical: a foreign banking subsidiary may be funded by domestic liabilities, but the equity exposure is transferred to the foreign company. Financial integration has increased these overall transfers of risk over time and the Bank for International Settlements (BIS) data show a sharp increase during the years running up to the crisis. For example, the increase in consolidated German banking claims on Spain during the upswing was equivalent to around $15 \%$ of Spanish GDP. In particular, the willingness of foreigners to take domestic risk has had an important effect on overall risk-taking by banks in smaller euro area economies experiencing domestic booms. While risk sharing is in principle a desirable feature of greater financial integration, if inappropriately managed it can increase vulnerability to shocks in other countries.

When the international financial crisis struck, many euro area countries were particularly exposed either to enormous credit risks in their own financial systems or through cross-border exposures. There was a marked contraction in cross-border banking and financial intermediation, with a sharp deterioration in the availability of finance to countries such as Greece, Ireland and Spain. This was managed through a combination of public support and heavy reliance on ECB funding. In the absence of a system of cross-border financial support, this added to fiscal pressures when public support was provided to the banking system. 


\section{Imbalances in some countries had spillovers for other monetary union economies}

The high degree of economic and financial integration between euro area countries creates numerous channels through which developments in one country may affect others. In particular, the monetary union contains a small number of larger countries: Germany accounts for over a quarter of euro area GDP, France around one-fifth and Italy for around one-sixth. Developments in these countries or in groups of highly correlated economies have the potential to create noticeable spillovers on others. Interdependencies between countries are not necessarily malign. For instance, a positive shock to technology in one country that temporarily raises interest rates and draws in capital from other euro area countries is an efficient reallocation of resources that benefits all, even if it temporarily reduces investment and consumption elsewhere. Openness yields valuable risk-sharing opportunities so that shocks in one country are partly shifted onto others. This lessens the overall impact of the shocks and all countries benefit from the ex ante insurance, even if some are negatively affected ex post. However, spillovers are more problematic if they transmit to others policy mistakes or lack of efficient adjustment in the domestic economy.

The strength of demand in one country can have effects on demand in other countries through the trade channel, both in the sense of changes in external demand and changes in the terms of trade as well as through third markets. These effects, however, are likely to be relatively small compared with other forces acting on the economy. Firstly, although euro area countries are relatively open by international standards, this degree of openness is by no means uniform with total exports accounting for not much more than a quarter of GDP in many of the large economies (Table 1). Furthermore, a large part of trade is with non-euro area economies. Some groups of countries are more closely interconnected: exports to Germany account for around one-fifth of national GDP in Austria, Belgium and the Netherlands. However, for most euro area countries, the exports to Germany account for less than 5\% of GDP, although imports are usually higher. Secondly, the effects of shifts of domestic demand and prices on export and import demand are modest for many categories of expenditure. Econometric evidence suggests that the marginal import propensity for euro area countries is around 0.2 for private consumption, 0.1 for public consumption and 0.4 for investment (Pain et al., 2005). Furthermore, the import propensity of exports is around 0.4 on average and higher for small open trading economies such as Belgium, Ireland and the Netherlands, where many imports are re-exported with little additional value added. Taken together, the size of trade with other euro area countries and trade elasticities suggest that the trade channel is likely to have a smaller effect than some other forces acting on the economy such as real interest rates. 
Table 1. Trade in goods and services by partner

As a percentage of GDP, 2007

\begin{tabular}{|c|c|c|c|c|c|c|c|c|}
\hline & \multicolumn{4}{|c|}{ Exports } & \multicolumn{4}{|c|}{ Imports } \\
\hline & Total & $\mathrm{EA}^{1} 3^{1}$ & $\begin{array}{l}\text { Other EU } \\
\text { (excl. CEE) }\end{array}$ & $\mathrm{CEE}^{2}$ & Total & $\mathrm{EA} 13^{1}$ & $\begin{array}{c}\text { Other EU } \\
\text { (excl. CEE) }\end{array}$ & $\mathrm{CEE}^{2}$ \\
\hline Austria & 57.6 & 30.6 & 3.5 & 6.8 & 53.1 & 31.6 & 2.4 & 4.8 \\
\hline Belgium & 111.7 & 66.8 & 11.6 & 3.6 & 106.6 & 61.8 & 10.0 & 2.6 \\
\hline Finland & 47.2 & 12.9 & 8.5 & 3.2 & 43.0 & 13.5 & 8.4 & 2.5 \\
\hline France & 26.8 & 12.7 & 3.1 & 1.1 & 29.4 & 14.3 & 3.4 & 3.2 \\
\hline Germany & 46.6 & 19.2 & 5.4 & 4.2 & 40.3 & 15.4 & 3.7 & 3.5 \\
\hline Greece & 21.6 & 6.6 & 3.6 & 1.4 & 31.2 & 13.5 & 2.8 & 1.2 \\
\hline Ireland & 82.0 & 31.5 & 18.3 & 1.6 & 70.3 & 18.2 & 18.3 & 0.8 \\
\hline Italy & 28.7 & 12.5 & 2.6 & 1.8 & 29.8 & 13.4 & 2.0 & 1.5 \\
\hline Luxembourg & 157.1 & 95.6 & 22.5 & 2.1 & 116.2 & 77.3 & 12.1 & 1.1 \\
\hline Netherlands & 76.1 & 40.8 & 10.2 & 3.5 & 67.5 & 29.1 & 7.1 & 1.9 \\
\hline Portugal & 33.5 & 20.0 & 3.9 & 0.5 & 41.7 & 26.7 & 2.6 & 0.6 \\
\hline Slovak Republic & 65.2 & 42.3 & 4.4 & 18.8 & 87.4 & 30.3 & 2.7 & 19.2 \\
\hline Spain & 26.7 & 13.5 & 4.4 & 0.7 & 34.3 & 16.6 & 3.3 & 0.9 \\
\hline
\end{tabular}

1. Euro area 13 countries (the ones listed in the first column).

2. Bulgaria, Czech Republic, Estonia, Hungary, Latvia, Lithuania, Poland and Romania.

Source: OECD, Monthly Statistics of International Trade.

The financial channel has proved a more powerful mechanism to transmit developments in one country to others through positions in financial markets, inter-linkages between financial institutions and changes in market valuations. Part of the expansion of credit during the upswing was financed through cross-border lending, particularly through the intermediation of domestic banks between the real economy and international banking markets. This conduit between savers and borrowers is in part a reflection of the effective allocation of capital in the EU single capital market and between euro area countries. However, it also provides a mechanism through which regulatory failures or imbalances can be transmitted from one economy to another. Once the credit cycle turned, these linkages created a range of negative spillovers between countries. National financial systems have been exposed to risks emanating from other euro area countries. There has been broader contagion between countries with banks in other countries facing higher funding costs because of lack of transparency about their exposures or concerns that they face the same risks as have been revealed in other countries. Banks in some countries have faced sudden stops with others withdrawing credit to them and exposing a large underlying liquidity mismatch.

The common euro area monetary policy stance may transmit shocks between countries if the euro area interest rate is changed in response to conditions in one country that have a material impact on the euro area as a whole. This effect partly offsets some of the spillovers between countries discussed above. While many euro area economies are too small to have a significant impact on the area-wide policy stance even if their situation is very far from the euro area average, developments in the larger countries or in groups of closely related economies may have a greater impact on the area-wide policy stance. For example, relatively low overall growth and weak domestic demand in Germany are likely to have kept euro area interest rates lower over the past decade than would otherwise have been the case, while a disproportionate share of inflation in the euro area as a whole can be accounted for by the overheating economies. 


\section{Large imbalances are leading to costly adjustment}

The unwinding of large imbalances has led to serious economic, financial and fiscal problems in some euro area countries, particularly in those with external deficits, weaknesses in competitiveness and high levels of indebtedness. During the initial fall in output, the experience across euro area countries was relatively similar. While activity in Ireland fell by almost $10 \%$ between 2007 and 2009, the GDP of Germany with a large external surplus also registered a relatively large fall of more than $6 \%$. However, the underlying causes of these developments was radically different: surplus countries with a high degree of openness were typically severely affected through the exposure to foreign trade, which contracted sharply towards the end of 2008 through a combination of confidence effects and also reliance on excessively strong demand in other countries. By contrast, the fall in output in deficit countries was dominated by the abrupt adjustment of internal imbalances.

While the rebound in global trade is helping surplus countries make up the losses, the weakening of the economies in deficit countries is more sustained due to credit constraints and the need to rebuild balance sheets (Figure 14). The sharp fall in demand in deficit countries is closely related to a rapid correction of underlying imbalances: between 2007 and 2009, the household saving ratio in Spain rose by 8.8 percentage points and by 7.6 percentage points in Ireland as consumers have needed to repay debt and rebuild their positions. In addition, there was a substantial tightening in the financial balance of the non-financial corporate sector, particularly in Ireland and Spain (EC, 2010b). At the same time, construction activity and house building collapsed where there had been housing booms. Unemployment has increased sharply in Ireland and Spain: the unemployment rate in Spain is close to $20 \%$, and is above $10 \%$ in Greece, Ireland and Portugal. This is consistent with international evidence that larger deficits have tended to take longer to adjust than smaller imbalances and have been associated with significantly slower income growth relative to trend during the current account recovery (Freund and Warnock, 2007), and that adjustment tends to be more severe where external imbalances were driven by consumption or strong banking flows. For countries that have borrowed heavily, repaying debts will be difficult if the funds have not been used to finance productive investment; much of the borrowing was used to finance private or public consumption and high rates of housing investment linked to booming house prices. While adjustment in surplus countries is likely to be less severe, they nevertheless remain sensitive to weaknesses in the recovery in world trade.

Figure 14. Deficit countries are experiencing the largest overall adjustment

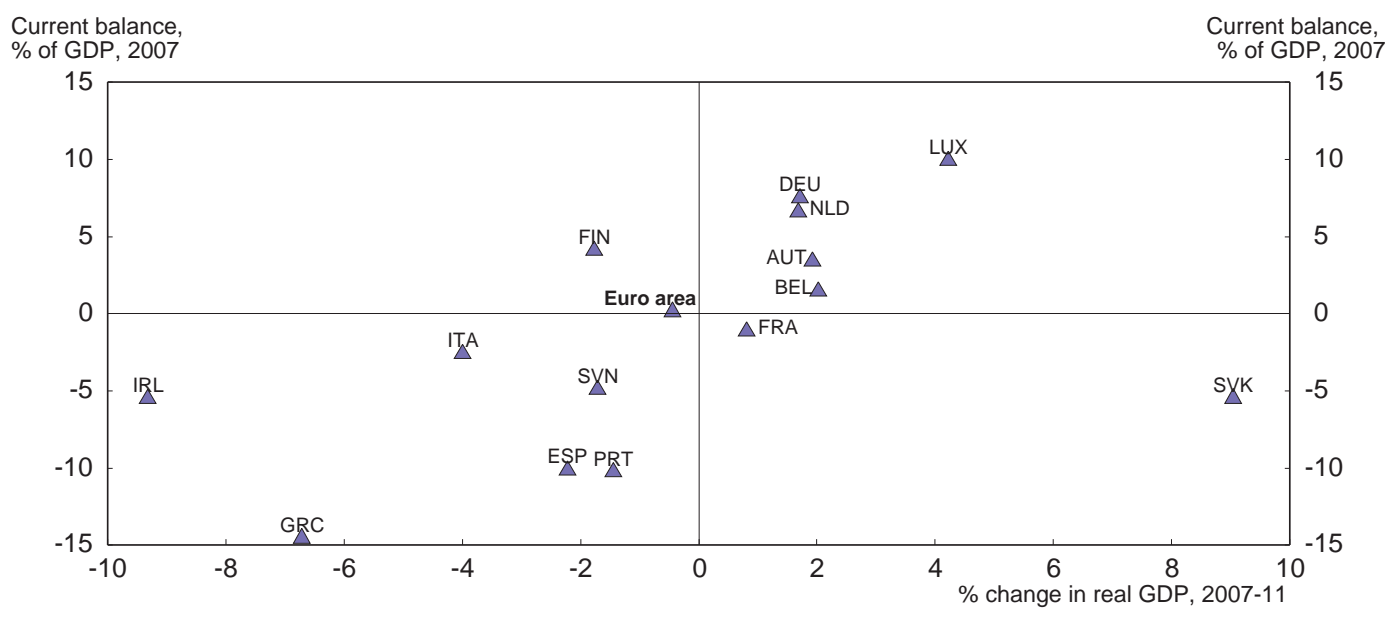

Source: OECD, OECD Economic Outlook 88 Database. 
Financial pressures have forced large adjustments and made economic rebalancing more difficult. Large monetary and debt overhangs in highly indebted countries have added to the rapidity and strength of pressures to rebuild balance sheets, thereby further depressing domestic demand. In addition, the housing and construction booms fuelled by credit in earlier years reversed sharply. Large borrower and surplus countries have experienced strong pressures on their financial systems. These in part reflect their heavy exposures to domestic credit cycles, asset prices and the high level of risk. These pressures were already evident before the international financial market turmoil began, with the housing boom in Ireland peaking in 2006 and the growth of housing activity in Spain already slowing. However, countries with high levels of debt were also extremely vulnerable to deteriorating conditions in international financial markets. In some cases, there was a sudden drop in confidence in economies with large current account deficits, leading to especially high credit spreads and restricted access to borrowing. As cross-border banking activity contracted, relatively small economies with high debts felt these effects most strongly. To date, losses and the costs of financial rescue have been particularly large in these countries. In addition, their reliance on ECB funding appears to have been especially high. The risk exposure of creditor countries is more difficult to assess as, while there have been losses on overseas activities of some banks, risks of lending to banks in other countries were partly absorbed through government rescues.

Weak demand and the end of credit booms have put pressure on government revenues and spending of borrower countries, while public support for financial rescues has led to substantial costs and increases in liabilities as private debt became public. The public debt-to-GDP ratio increased between 2007 and 2009 by almost 40 percentage points in Ireland, 19 points in Greece and 17 points in Spain. These countries have been unable to allow even the automatic stabilisers to function fully and so discretionary policy has been pro-cyclical. ${ }^{13}$ Given these deteriorating positions and greater sensitivity to risk, credit spreads to high debt countries increased markedly.

\section{Measures to restore stability in the near and longer term are needed at European and national level}

The scale of economic, financial and fiscal imbalances in the euro area has brought to the fore the importance of conducting national policies consistent with the requirements of the monetary union. While the creation of the euro has brought many benefits, recent developments have highlighted the greater challenge of stabilising national economies inside a monetary union, that can lead to macroeconomic and financial imbalances at national level. At the same time, the euro area and EU oversight failed to prevent or react to the build-up of large imbalances. As growth rates are likely to continue to be diverse among euro area countries, the functioning of the monetary union needs to be strengthened by a broader set of policies aimed at addressing the sources of imbalances. The immediate priority is to deal with the financial, economic, fiscal and social consequences of the imbalances that have accumulated over recent years. However, a new cross-cutting approach needs to be undertaken to reduce the risks and costs of future imbalances. This would lead to a more complete and successful monetary union. This section sets out the framework for tackling these problems. Putting fiscal policy on a sounder footing also a key issue and there is an important role for improved financial and macroprudential oversight. Structural policies can also play an important role in resolving and avoiding imbalances.

13. In the case of Spain, discretionary fiscal stimulus was used to cushion the initial impact of the crisis but this was more than unwound by subsequent retrenchment at a time when overall demand has been very weak. 


\section{Restoring macroeconomic and financial stability is an immediate priority}

Before sustainable recovery can begin, weaknesses in the financial system need to be repaired, so that normal credit intermediation is able to support the economy, and fiscal policy must be placed on a sustainable path. While this holds in the euro area as a whole, this is especially important for countries where borrowing proved excessive. Considerable progress has been made in this direction in a number of countries. In addition to measures to provide temporary support to the financial system, Ireland and Spain have taken comprehensive measures to resolve banking sector weaknesses. In Ireland, the National Asset Management Agency (NAMA) is taking property-related loans off banks balance sheets, alongside government capital injections and the nationalisation of some banks (OECD, 2009b). In Spain, saving banks (cajas) have been restructured and in some cases recapitalised. To improve fiscal sustainability in the face of rising credit spreads, dramatic consolidation measures have been taken in Greece, Ireland, Portugal and Spain.

External imbalances in euro area countries have narrowed since their peak. The current account surplus in Germany fell from 7.7\% of GDP in 2007 to 5\% in 2009, while Spain's position narrowed from a deficit of almost $10 \%$ of GDP to $5.4 \%$. The changes in the external position reflect substantial adjustments in the economic imbalances within different euro area countries. In particular, there have been sharp reductions in private domestic demand in Ireland and Spain (Figure 15). However, some corrections are cyclical and are likely to reverse as economies recover. Furthermore, the reduction of domestic imbalances has left output below potential, especially in the most severely affected countries.

Figure 15. Contribution to total domestic demand growth

Contribution to change between 2008 Q1 and 2010 Q2, at annual rate

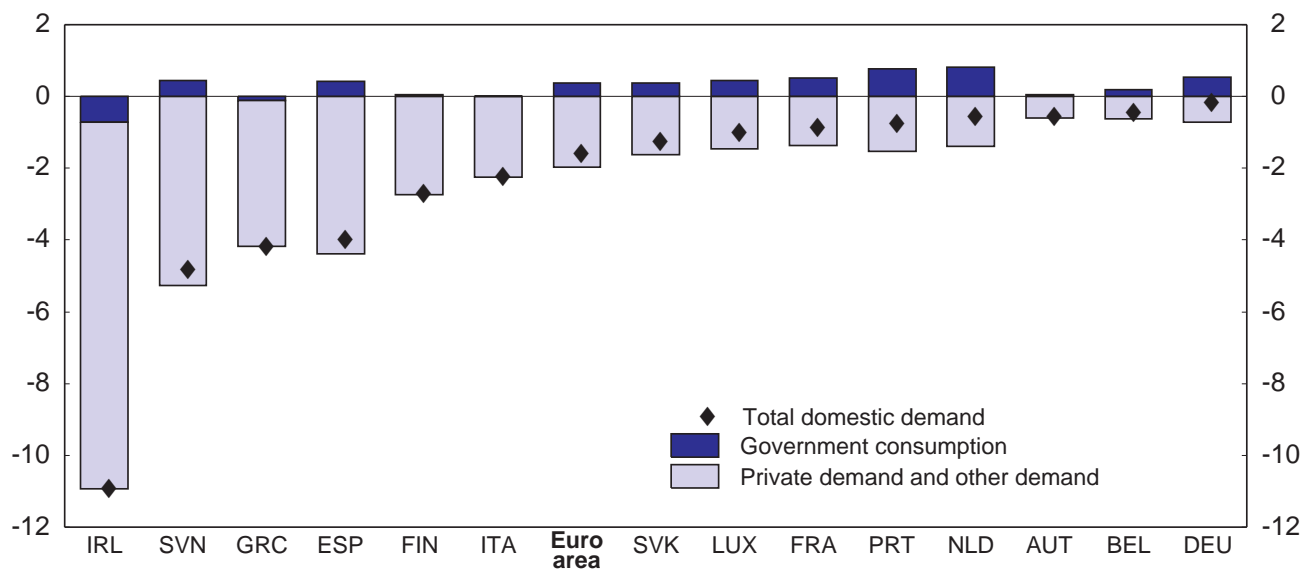

Source: OECD, OECD Economic Outlook Database.

\section{Imbalances need to be reduced to sustainable levels}

Lasting rebalancing of euro area economies will be achieved when activity returns closer to its sustainable level and external accounts are realigned with levels justified by economic fundamentals. In the short run, there is a case to continue to support demand during period of adjustment. Overall, euro area monetary policy stimulus will help all economies to recover but this will be insufficient for countries with the most severe downturns. The room for fiscal support at the national level is, however, in some cases severely constrained. In addition, action is required to rebalance economies with large imbalances. Surplus countries need stronger demand for non-tradeable goods, while making efforts to increase productivity in this sector. At the same time, deficit countries need to switch demand away from imports and output towards producing for export. Saving needs to moderate, where 
it is excessive, and debt repayment is required in countries that have become heavily indebted. To the extent that high or low rates of saving reflect inefficiencies and structural rigidities, reforms should be undertaken to eliminate these impediments.

Government demand has provided some support to economies undergoing severe adjustment, although this has been limited in countries such as Ireland and Greece by pressures on the fiscal position. While fiscal consolidation is required in these countries, it is vital that the path to rebalancing the economy and the public finances allows for some time to adjust and that there is not an abrupt and inefficient realignment. Debtor countries need to be able to continue to finance their debts, while running down the overall stock of outstanding commitments. If the availability of credit to domestic private borrowers were to suffer a liquidity shock, it is likely that governments would step in to support them. It is therefore essential that solvent governments have continued access to finance. In the short run, the European Financial Stability Facility (EFSF) is available subject to conditionality to provide liquidity insurance for euro area countries. More fundamentally, it is crucial that governments take measures to reduce the risks of liquidity shocks materialising by pursuing ambitious and sufficiently front-loaded fiscal consolidation policies with medium-term orientations, supported by structural reforms to facilitate the fiscal adjustment.

The required adjustment will be a difficult and prolonged task. In deficit countries, improving external competitiveness would help to boost external demand and maintain employment in the short run. An overall decline in relative prices is required to return to a sustainable position over the longer term, as well as to increase exports to repay foreign debts. Without the flexibility to devalue the nominal exchange rate, this will require considerable wage and price restraint, and falls in the price level cannot be ruled out in some economies. Evidence based on past adjustment of current accounts in industrialised countries suggests that, in the absence of nominal exchange rate flexibility, rigidities in domestic prices are harmful for growth (EC, 2010a). The required change in relative prices, however, is large: it would take five years of flat prices in Greece, Ireland, Portugal and Spain with inflation at $2 \%$ in other euro area countries for real exchange rates to return to their 1999 level, although this exercise is likely to give an upper bound as the initial position may not have been an equilibrium (OECD, 2010a). Furthermore, the impact on demand of improved external price competitiveness would be relatively weak in countries such as Greece and Portugal that have a low openness to trade. There is some indication that this adjustment is already underway: Ireland has been experiencing a period of deflation since late 2008 and the price level measured by the core national consumer price index is close to $7 \%$ below the peak. Inflation in other deficit countries has also been weak. Over the short term, weak or negative inflation will tend to increase the real interest rate, which will dampen the recovery by delaying consumption and reducing investment.

Achieving the necessary price adjustment will also be difficult, particularly where labour market institutions lead to nominal wage rigidity. Wage adjustment has played an important role in moderating the impact of adjustment on growth during past current account adjustment episodes (EC, 2010a). Although formal wage indexation only applies in a small number of countries (including Spain), informal arrangements or the structure of wage bargaining more generally can make it difficult to adjust wages downwards. As Portugal has shown over the past decade, price rigidities can lead to the economy remaining depressed for many years. Government policy in most cases can have only limited direct impact on private sector wages and prices. However, labour market regulations can impinge on private sector wages and the bargaining process. Furthermore, public employment will influence overall demand for labour and the public sector wages may provide an important signal for private wage setters. Consolidation plans in Greece, Ireland and Spain have included nominal cuts in public wages. Important labour market reforms currently underway in Spain could also make a useful contribution to the adjustment process. 
Any process of deflation needs to be carefully managed. In principle, the risk of a deflationary spiral induced by unstable inflationary expectations should not apply for individual euro area countries as inflation expectations would be anchored by the ECB's definition of price stability, and the fall in prices would necessarily help to depreciate the real exchange rate. There is very little guide at all in the past experience of OECD members about deflation with only Finland and Japan having experienced marked deflationary phases. Even in the case of Japan, the decline in the price level has been fairly moderate. One problem with deflation is that falling prices increase the real value of debts denominated in nominal terms, exacerbating the nominal debt overhang. The debt-deflation trap (Fisher, 1933) could slow the recovery in private demand and contribute to budgetary pressures, both by increasing the real value of debt and by reversing nominal fiscal drag.

Structural policies have a key role to play in rebalancing economies, and higher productivity can ease the burden on wage and price adjustment where competitiveness is weak. For countries with large current account deficits, reforms to make product markets more competitive would improve productivity (Boulhol and Turner, 2008). In the tradeable goods sector, this would help to make goods more attractive on world markets, while fewer barriers to competition in the non-tradeable services sector would lower prices and help to switch resources to other activities. Detailed recommendations in this direction have been made in recent OECD Economic Surveys for Greece, Ireland, Portugal and Spain. For countries with high debts, structural reforms that raise growth would make debts easier to repay and sustain. For countries with large external surpluses, structural reforms in the services sector of the economy would both raise the overall performance of the economy, support internal demand overall and help to switch demand towards consumption of domestic production (OECD, 2010b). For example, aligning the level of economy-wide product market regulation in Germany with OECD best practice could raise private investment by 0.7 percentage points of GDP (Koske et al., 2010).

\section{Improving national macroeconomic and financial management to avoid future imbalances}

While the exact sequence of events that led to the current imbalances is unlikely to recur, the risk of future imbalances will remain unless policies are put in place to improve macroeconomic management. The imbalances built up over the 2002 to 2007 period partly reflect idiosyncratic factors, notably pressures on catching up economies stemming from the creation of monetary union itself and an unusually pronounced global credit cycle. Future shocks could stem from structural changes such as different demographic developments or productivity trends, as well as through errors in the setting of policy or financial regulations. While small deviations from internal and external balance are inevitable, the key challenge is to avoid large, persistent and costly imbalances of the kind built up during the past decade.

The likelihood of shocks that can lead to such imbalances depends partly on the degree of similarity across countries. The endogenous optimal currency theory suggests that this may increase over time inside a monetary union (Frankel and Rose, 1998). Although there is evidence that monetary union membership has increased integration through trade and foreign direct investment decisions (Warin et al., 2009), this integration remains incomplete. While greater integration may help to reduce the possibility of asymmetric shocks, greater specialisation in production may have the opposite effect. Financial integration that improves risk sharing may help to stabilise nominal demand. However, this also remains imperfect and greater financial integration may aggravate the impact of shocks by generating stronger wealth effects (Hoeller et al., 2002). Moreover, regulations affecting price and wage nominal flexibility and employment protection play a role in the adjustment mechanism and matter for the extent to which common shocks may have country-specific effects on price competitiveness (Biroli et al., 2010). 
Given that area-wide monetary policy cannot address local imbalances, these are primarily the responsibility of individual euro area countries. Furthermore, most of the costs of the failure to stabilise the national economy fall on the domestic population. In this sense, an imbalance is a first-order issue for the country concerned and a second-order issue for other countries that are exposed to some of the same risks. Nevertheless, the potential for cross-border spillovers is important and can justify imbalances at national level being treated as a matter of concern for the euro area as a whole. Macroeconomic management of the domestic economy needs to be given a high priority as it cannot be assumed that area-wide policy will be sufficient to balance each economy. In a similar way to how monetary policy is set, there needs to be a clear and timely assessment of the state of the economy, the forces acting on it and the risks. A range of policy tools is then needed to manage the domestic economy and financial system in a similar way to that which would occur with national monetary policy if this were available. This can mean that national policy settings may need to diverge from their area-wide level, within an overall framework of sound and sustainable positions. For example, a system of counter-cyclical capital buffers for banks applied to national conditions could help to achieve this outcome.

\section{Structural reforms would reduce the risk of imbalances}

Structural reforms have an important role to play as current account imbalances are driven partly by domestic structural policy settings in financial, product and labour markets as well as tax and benefit systems. The primary goal of structural policies is to raise living standards. At the same time, they can have important effects on the saving and investment decisions of households and firms as well as on public saving and investment (Blanchard, 2007). Structural policies also influence the speed at which firms and households adjust saving and investment behaviour to changes in macroeconomic conditions. There is evidence that higher social spending, higher unemployment benefits and stricter employment protection legislation (EPL) are associated with a lower saving rate and a weaker current account, most likely reflecting lower precautionary saving of households (Koske et al., 2010).

Structural reforms to increase economic flexibility would not only help to deal with the consequences of imbalances but would also help to ensure that economies tend to develop in a more balanced way, both for those with excess demand but also where demand for domestic production has been weak. Economic structures need to be adapted to the disciplines of monetary union. It is essential that wage increases are kept in line with productivity to avoid distortions in competitiveness. There is a wide range of wage bargaining institutions in euro area countries. While there are few general conclusions about the optimal design of wage bargaining institutions, ${ }^{14}$ it is important that they work well. The explicit role of governments in private-sector wage setting is typically limited, although public sector wages influence private wage bargaining (Lamo et al., 2008). However, labour market institutions can have an impact on how these mechanisms work and the government may have an informal role in the process. Automatic wage indexation, which exists in various forms in Belgium, Luxembourg, Slovenia and Spain, can be a significant barrier to adjustment. The legal extension of pay deals to the whole sector is particularly problematic as unions neither fully internalise the costs of their actions nor is the outcome close to a decentralised market outcome (Calmfors, 1993).

\section{Sound fiscal policy at national level should be the counterpart of ECB monetary policy}

In the absence of national monetary policy, fiscal policy is an instrument for macroeconomic management at national level. In the absence of substantial fiscal transfers between countries, temporary shocks in euro area countries need to be stabilised through changes in the fiscal balance,

14. See Chapter 3 "Wage-setting Institutions and Outcomes" of OECD (2004). 
leading to the appropriate capital flows operating through capital markets rather than a federal budget. Fiscal policy should be set so that the automatic stabilisers are allowed to operate, both in good times where there is temptation to spend booming revenues and during downturns. Unsustainable fiscal policies should not be allowed to contribute to wider imbalances, although generally it was private sector imbalances that have been the major driver over the past decade. In addition, there needs to be the scope to deal with emergencies, such as problems in the financial sector. This implies that the outstanding debt stock should be kept at a prudent level. The scope of discretionary policy aimed only at changing the overall fiscal stance is unlikely to have strong effects in many countries, not least due to leakages abroad as well as offsets in private behaviour, and must in any case take into account the sustainability of the public finances. Such an approach would be second-best in the sense that it does not necessarily directly address the underlying causes of private sector imbalances. Within these constraints, some targeted fiscal policy actions could help more closely to address imbalances, such as by changing government spending on non-tradeable goods or through targeted tax measures such as reducing support for housing. For example, a package of measures put in place in Ireland between 1998 and 2002 including these elements had a dramatic effect on holding back house price growth, although these measures were ultimately reversed. ${ }^{15}$ Fiscal policy in this sense should aim to minimise market distortions.

Stabilisation through fiscal policy in the wake of the crisis has played an important role in supporting domestic demand in the short run in countries where private demand has contracted sharply as overstretched borrowers sought to rebuild their balance sheets. Although sustainable public finances are a pre-condition for providing this support, heightened risk aversion may make it difficult for countries to borrow even where this would appear to be justified. This can be provided in a number of ways, including self-insuring through the creation of rainy day funds, or a system of pooled insurance. The latter is more efficient to the extent that shocks are not correlated across countries. A permanent mechanism should be put in place to deal with liquidity crises, incorporating strong conditionality.

\section{Macroprudential policies need to be differentiated at country level}

Enhanced regulation could be used to address financial imbalances, including those whose origins lie in destabilising movements in real interest rates at national level. More effective and better enforced microprudential regulation could help to reduce excessive risk-taking and protect the financial system from pressures caused by strong loan demand and excessively high asset valuations. Stronger microprudential regulation and supervision should make financial systems more robust to these pressures and increase the resilience of the financial system when risks materialise. In addition, the creation of an effective system of macroprudential regulation could serve both to ensure the sustainability of the financial sector and to limit the consequences on the macroeconomy of credit cycles.

The highly international nature of EU capital markets, which also carries many advantages, needs to be taken into account in the design of appropriate policies. Heavy external borrowing has been associated with particular financial risks in euro area countries due to high capital mobility, especially the flow of funds and the transfer of risks between banks in different countries. There is a particular need to:

- Set macroprudential policies on a national or sub-national level, in addition to on a euro area and EU-wide basis. These need to apply to all credit to a particular country, irrespective of

15. See Box 1. "Tax breaks for housing and policy flip-flops" in Rae and van den Noord (2006). 
the location or identity of the lender, through the principle of jurisdictional reciprocity. Quasi-automatic capital buffers based on national credit growth should be a key instrument.

- National concentrations of risk should be systematically considered under Pillar II of the Basel system for determining regulatory capital.

- Liquidity regulation should be stepped up to reduce mismatches where banks use access to the interbank market to draw in funds from other countries to finance long-term domestic lending.

More comprehensive financial integration, including at the retail level, within an appropriate regulatory and supervisory framework would reduce local risk concentrations. As discussed above, the structure of the euro area financial system with high levels of integration in some businesses but not others has an inherent tendency to create fragility. Firstly, it intensifies local financial accelerator effects. Secondly, by easing credit constraints, it can lead to short-term capital flows that contribute to risk-taking in the domestic economy and increase the vulnerability of liquidity risks. Thirdly, limited retail integration implies that lenders will often be far away from the risks to which they are exposed and this increases asymmetric information. In addition, more intensive, and better regulated and supervised financial integration could help to reduce the risk of adverse effects from financial imbalances, but would not deal directly with this risky structure.

Greater attention is needed to the cross-border implications of large exposures on national balance sheet. In the absence of any cross-border mechanism, each euro area country has remained responsible for providing assistance to institutions in its jurisdictions or with a systemic impact in that country. This has posed a very serious financial burden on some countries. In federal systems, there is typically a federal safety net. For example, the US Federal Deposit Insurance Corporation (FDIC) provides a federal system of insurance linked to federal supervision.

Removing distortions in housing policies should reduce the volatility of housing markets. The housing cycle generated by low real interest rates was amplified by tax distortions in favour of owneroccupied housing and land use restrictions, as discussed above. In particular, favourable tax treatment through mortgage deductibility and generous tax relief for housing transactions should be curtailed. This would also contribute to improving structural budget positions. Furthermore, residential mobility in euro area countries is typically low with the number of households that changed residence within the last two years generally below the OECD average (Andrews et al., forthcoming). Reforms that improve the functioning of the housing market, such as reducing high transaction taxes and removing supply constraints, could also facilitate economic adjustment by removing barriers to labour mobility.

\section{Stronger European surveillance and policy co-ordination}

Enhanced European surveillance and coordination of economic policies could help to increase the effectiveness of national policies to avoid imbalances. Co-ordination of policies could in principle take different forms, along a spectrum running from peer review and benchmarking through enforcement of common standards to co-ordinated use of discretionary policy. Such policies could be justified on at least two grounds. Firstly, to the extent that there are spillovers between euro area countries, the pursuit of sound national policies is even more important and should clearly be seen as an issue of common interest elsewhere. Secondly, closer co-ordination and reinforced surveillance of economic policy may help national authorities in setting policy and committing to policies that are otherwise difficult to apply. Within the context of the European Union, co-ordination around imbalances should be strongest with respect to euro area countries: these countries are in general the most economically and financially integrated, as well as sharing the same currency and central bank. In addition, 
euro area economies are more difficult to stabilise in the absence of nominal exchange rate flexibility and independent national monetary policy.

The scope for gains from policy co-ordination is determined by the size of spillovers. As argued above, trade spillovers are likely to be fairly weak, so other economies would generally have little to gain through a change of policy settings in another country. Indeed, changing overall demand for goods in one country would be a very indirect method of trying to help another economy to achieve balance. However, financial spillovers have been very large. The overall stress in euro area financial markets relates partly to weaknesses in specific countries. The crisis around sovereign debt in May 2010 had severe effects on many euro area countries, even though Greece accounts for less than $3 \%$ of euro area GDP. For example, the timing of movements in the euro area exchange rates, increases in credit spreads on the debt of other euro area countries and the state of the interbank market closely followed news about the situation in Greece. The size of capital movements between countries can have very large effects on individual countries, both during the upswing of the credit cycle and in a crisis. Given the nature of spillovers, the underlying factors behind both excess saving and consumption or investment should be treated as issues of concern.

\section{EU and Euro Group surveillance needs more teeth}

Surveillance of economic imbalances has long been undertaken at international level, both by the EU institutions and other international organisations. This has complemented analysis by national authorities, institutions and commentators. Extensive international warnings have been issued in the past about the risks from imbalances in the domestic economies of euro area countries, both for deficit countries such as Greece, Ireland, Portugal and Spain and for those running large surpluses but with sluggish domestic demand such as Germany. Surveillance of imbalances by the Commission has long been an integral element of its on-going monitoring of economic developments and policies in the euro area and other EU countries. This assessment has appeared regularly in the Euro Area Annual Report, published since 2006, and was discussed earlier in editions of the EU Economy Review and the Quarterly Report on Euro Area. Substantial analytical work on imbalances was published in The EU Economy: 2006 Review (EC, 2006). This work is followed up in the Surveillance of Intra-Euro Area Competitiveness and Imbalances (EC, 2010a). The ECB has also stressed the importance of internal and external competitiveness in the Euro Group since at least 2005 . $^{16}$

There appears to be a high level of agreement about the risks of imbalances prior to the crisis. Based on the position of six euro area countries around 2001, the assessment of the cyclical position and warnings about overheating/excess demand were "similar" from the EU Council, the IMF Executive Board and the OECD (Hoeller et al., 2002). Such assessments are generally based on a broad range of indicators, although the 2001 study indicated that the ranking of risks across countries closely followed the inflation ranking. One key difficulty is assessing potential output, which is unobservable but crucial to any judgment about whether imbalances are excessive. For the same reasons, estimating Balassa-Samuelson-type effects on inflation related to productivity shocks in the tradeable goods sectors is difficult and makes it hard to judge the degree to which inflation is driven by excess demand. For the group of six countries in 2001, there was a "wide range of results" in terms of how far inflation differentials were driven by underlying factors (Hoeller et al., 2002). Overall, the ex ante identification about some of the imbalances was correct but the scale and nature of the problem was not fully understood or appreciated. There is nevertheless scope to improve surveillance at EU level, including a particular focus on the specific issues facing euro area economies. This should

16. See introductory statement by Jean-Claude Trichet at the Hearing at the Economic and Monetary Affairs Committee of the European Parliament in Brussels on 21 June, 2010. 
emphasise the extent to which imbalances are judged to be excessive and the risks involved. While countries should ultimately be the best placed to understand their economic situations, EU surveillance can bring a wider perspective and draw on the experience and benchmarks provided by other countries.

Over the recent build-up of imbalances, there was insufficient policy action in response to warnings from the Commission and other bodies. At national level, such warnings were not treated as credible or were ignored, particularly because the necessary policy instruments and institutional frameworks were not in place. At the EU and euro area level, the ECOFIN Council and the Euro Group each provided a forum to discuss these issues. However, effective policies did not emerge from these discussions. The only well-defined instrument in this area was the adoption by the Council of Broad Economic Policy Guidelines (BEPGs), a reference document intended to guide the conduct of the whole range of economic policies at national and EU level. The key feature of the BEPGs in terms of policy co-ordination was the power given in the Treaty to issue a recommendation that corrective action be taken when economic policies "risk jeopardizing the proper functioning of economic and monetary union". The policy guidelines have been framed in recent years in terms of stability and sustainability, which could be applied to the problem of imbalances. However, while the BEPGs appear to have had some benefits in stimulating useful discussion about these and other economic issues, peer pressure has not been effective either in enforcing it at the EU level or triggering "home grown" forces to deal with economic weaknesses (Deroose et al., 2008). In particular, only one recommendation to take corrective action was ever issued, to Ireland in 2001, and the strongly negative political reaction to this event appears to have effectively put an end to this initiative. Recent discussions in the Euro Group have also touched on issues related to imbalances. It is difficult to assess the impact of these meetings as they are closed, but the lack of transparency in itself hinders some of the mechanisms that could make peer review effective. ${ }^{17}$

In response to the lack of an effective enforcement mechanism in the past with respect to harmful imbalances, important legislative changes are underway to improve the identification of imbalances in the EU and to help ensure that the necessary corrective action is taken through an enforcement mechanism. Current proposals follow a two-stage approach. In the first stage, there would be an annual assessment of the risk of macroeconomic imbalances and vulnerabilities in EU countries by the Commission (EC, 2010c; EU Taskforce, 2010). This would be based on a scoreboard of macroeconomic and financial indicators with lower and upper thresholds set as alert levels. This could include variables such as the current account balance, the net investment position, measures of competitiveness, credit growth and changes in house prices. The Commission would conduct an in-depth review, incorporating a wider range of information and qualitative assessment, to determine whether the imbalances pose a risk. Assessing the balance of domestic demand and supply, as well as potential output, should play a key part in this analysis. It is important in selecting indicators and calibrating alert levels to achieve the appropriate balance of Type I (falsely identifying potential harmful imbalance) and Type II (failing to identify risk imbalances) errors. The costs of failing to identify growing vulnerabilities are high, while the in-depth review following initial identification based on the scoreboard would help to minimise the consequences of Type I errors originating from the scoreboard. Nevertheless, a system of indicators that failed to discriminate sufficiently between different countries and led to perpetual in-depth reviews of a large number of countries could lose credibility and political support. Monitoring of macroeconomic imbalances would be integrated with other elements of surveillance, notably of fiscal and structural policies, through the "European semester" (EC, 2010a). Given the importance of financial spillovers, it is of particular importance that the assessment, warnings and recommendations of the European Systemic Risk Board (ESRB) are

17. “La France va évaluer la compétitivité de l’Allemagne”, Le Figaro, 13 July, 2010. 
taken fully into account and that the ESRB undertakes detailed analysis of cross-border capital flows and risk concentration. The new calendar for surveillance would contribute to a broad-based assessment of policy settings that can lead to harmful imbalances.

The second stage of the proposed approach is to introduce enforcement to ensure that economic policies of EU countries do not pose risks through imbalance to the proper functioning of economic and monetary union (EC, 2010c; EU Taskforce, 2010). The Commission would have the power to issue an early warning if problems were identified during the in-depth review. In the case of serious imbalances, the Council could place a country in an "Excessive Imbalance Position" based on a recommendation from the Commission, which would have to be rejected by a qualified majority under the new "quasi-automatic" voting procedure. A set of financial or structural policy recommendations would be addressed to the country in question, which would be required to report regularly on progress. The Commission would also monitor implementation. Some of the policies required to deal with imbalances are not within the direct control of the government; for example, wages are largely determined in the private sector. Therefore, policy recommendations and their monitoring would focus primarily on the existence of appropriate policies, rather than just the outcome in terms of imbalances. For euro area countries only, repeated non-compliance with the Council's recommendations could ultimately lead to fines along the lines of those that exist for non-compliance with the Stability and Growth Pact.

The implementation of these proposals would be a major upgrading of the surveillance of euro area imbalances and create a more developed enforcement mechanism. Nevertheless, it could remain difficult to ensure that appropriate corrective action is taken. In particular, the identification of harmful imbalances and how to resolve them is inherently complicated and requires some judgment. Defining "excess imbalances" is, for example, likely to be more difficult than identifying an "excessive deficit", which is more closely based on simple numerical criteria. It requires a stronger element of judgment based on a broader range of indicators, which can create ambiguities about whether action is required or what form this should take. The enforcement of such decisions around the Broad Economic Policy Guideline by the Council has proven to be ineffective in the past, even more so perhaps than for fiscal policy. In particular, the warning given to Ireland in 2001 by the Council led to a political reaction and triggered a debate about the legitimacy of EU economic governance (Deroose et al., 2008). Such warnings were subsequently not invoked again. The effectiveness of the new institutions should be kept under review and, if achieving the necessary corrective action proves difficult, consideration could be given to a simple quantitative standard that would create a clearer presumption of policy action to address imbalances as a backstop. The lack of effective action in the past in response to imbalances and growing vulnerability needs to change. The possible difficulties in achieving effective enforcement need to be overcome and the difficulties involved should not be a deterrent to put in place procedures to identify, avoid and correct harmful imbalances that threaten to jeopardise the proper functioning of the euro area. 


\section{Bibliography}

Abbas, A. et al. (2010), "Fiscal Policy and the Current Account", IMF Working Paper, No. 10/121, Washington DC.

Ahrend, R. (2010), "Monetary Ease: A Factor behind Financial Crises? Some Evidence from OECD Countries", Economics E-Journal, Vol. 4, 2010-12.

Andrews, D., A. Caldera Sanchez and A Johansson (forthcoming), "Housing Markets and Structural Policies in OECD Countries", OECD Economics Department Working Papers, OECD, Paris.

Angeloni, I. et al. (2003), "Monetary Transmission in the Euro Area: Does the Interest Rate Channel Explain it All?", NBER Working Paper, No. 9984.

Balassa, B. (1964), “The Purchasing Power Doctrine: A Reappraisal”, Journal of Political Economy, No. 72.

Barnes, S., P. Lane and A. Radziwill (forthcoming), "Minimising risks from imbalances in European banking", OECD Economics Department Working Papers, OECD, Paris.

Barnes, S., J. Lawson and A. Radziwill (forthcoming), "Current Account Imbalances in the Euro Area: A Comparative Perspective", OECD Economics Department Working Papers, OECD, Paris.

Bennett, H. et al. (2008), "Competitiveness in the Southern Euro Area: France, Greece, Italy, Portugal and Spain", IMF Working Paper, WP/08/112.

Bernanke, B. and M. Gilchrist (1995). "Inside the Black Box: The Credit Channel of Monetary Policy Transmission", Journal of Economic Perspectives, Vol. 9 (Fall).

Biroli, P., G. Mourre and A. Turrini (2010), "Adjustment in the Euro Area and Regulation of Product and Labour Markets: an Empirical Assessment”, CEPR Discussion Paper, No. 8010.

Blanchard, O. (2007), "Current Account Deficits in Rich Countries", IMF Staff Papers, Vol. 54, pp. 191-219.

Blanchard, O. and F. Giavazzi (2002), "Current Account Deficits in the Euro Area: The End of the Feldstein Horioka Puzzle”, Brookings Papers on Economic Activity, Vol. 33. Issue 2002-2.

Boulhol, H. and L. Turner (2008), "Recent Trends and Structural Breaks in US and EU15 Labour Productivity Growth”, OECD Economics Department Working Papers, No. 628, OECD, Paris.

Calmfors, L. (1993), "The Extent of Centralisation of Wage Bargaining and Macroeconomic Performance”, OECD Economics Department Working Papers, No. 131, OECD, Paris.

Catte, P. et al. (2004), "Housing Markets, Wealth and the Business Cycle", OECD Economics Department Working Papers, No. 394, OECD, Paris.

Cheung, C., D. Furceri and E. Rusticelli (2010), "Structural and Cyclical Factors behind Current-Account Balances", OECD Economics Department Working Papers, No. 775, OECD, Paris. 
Chinn, M. and E. Prasad (2003), "Medium-Term Determinants of Current Accounts in Industrial and Developing Countries: An Empirical Exploration”, Journal of International Economics, Vol. 59, Issue 1.

Corden, W. and J. Neary (1982), "Booming Sector and De-industrialisation in a Small Open Economy”, The Economic Journal, Vol. 92, December.

Corsetti, G. (2008), “A Modern Reconsideration of the Theory of Optimal Currency Areas", European Economy Economic Papers, No. 308, March, Brussels.

Deroose, S., D. Hodson and J. Kuhlmann (2008), "The Broad Economic Policy Guidelines: Before and After the Re-launch of the Lisbon Strategy", Journal of Common Market Studies, Vol. 46, No. 4.

Égert, B. (2010), "Catching-up and Inflation in Europe: Balassa-Samuelson, Engel's Law and Other Culprits", OECD Economics Department Working Papers, No. 792, OECD, Paris.

Égert, B. and R. Kierzenkowski (2010), "Exports and Property Prices in France: Are They Connected?", OECD Economics Department Working Papers, No. 759, OECD, Paris.

European Commission (EC) (2006), "The EU Economy: 2006 Review; Adjustment Dynamics in the Euro Area - Experiences and Challenges”, European Economy, No. 6, European Commission, Brussels.

EC (2009), "Competitiveness Developments in the Euro Area", Quarterly Report on the Euro Area, Volume 8, No. 1, European Commission, Brussels.

EC (2010a), "Surveillance of Intra-Euro-Area Competitiveness and Imbalances", European Economy, No. 1, European Commission, Brussels.

EC (2010b), Quarterly Report on the Euro Area, Volume 9, No. 3, European Commission, Brussels.

EC (2010c), Proposal for a Regulation of the European Parliament and of the Council on the Prevention and Correction of Macroeconomic Imbalances, 29 September, Brussels.

EC (2010d), Proposal for a Regulation of the European Parliament and of the Council on Enforcement Measures to Correct Excessive Imbalances in the Euro Area, 29 September, Brussels.

EC (2010e), "A look at Past Episodes of Current Account Adjustment", Quarterly Report on the Euro Area, Vol. 9, No. 3.

ECB (2010), Financial integration in Europe, April.

EU Taskforce on Economic Governance (2010), "Strengthening Economic Governance in the EU", Report of the Taskforce to the European Council, 21 October, Brussels.

Faruqee, H. and J. Lee (2009), "Global Dispersion of Current Accounts: Is the Universe Expanding", IMF Staff Papers, No. 56.

Fisher, I. (1933), “The Debt-Deflation Theory of Great Depressions”, Econometrica, Vol. 1, No. 4, October.

Flemming, J. (1962), "Domestic Financial Policies under Fixed and Floating Exchange Rates", IMF Staff Papers, No 9, November, Washington.

Frankel, J. and A. Rose (1998), "The Endogeneity of the Optimum Currency Area Criteria", Economic Journal, Vol. 108, July. 
Freund, C. and F. Warnock (2007), "Current Account Deficits in Industrial Countries: The Bigger They Are, The Harder They Fall?" in Clarida, R. (2007) (ed.), G7 Current Account Imbalances: Sustainability and Adjustment, NBER.

Fuentes Castro, D. (2010) "Leverage and Bubbles: a Note on the Spanish Property Market between 1998 and 2006", Applied Economic Letters, forthcoming.

Galí, J. and M. Gertler (1999), "Inflation Dynamics: A Structural Econometric Analysis", Journal of Monetary Economics, Vol. 44, Issue 2, October.

Hayashi, F. and E. Prescott (2002). "The 1990s in Japan: A Lost Decade", Review of Economic Dynamics, Vol. 5(1), pp. 206-235, January.

Hoeller, P. et al. (2002), "Overheating in Small Euro Area Economies: Should Fiscal Policy React", OECD Economics Department Working Papers, No. 323, OECD, Paris.

Hoeller, P. and D. Rae (2007), "Housing Markets and Adjustment in Monetary Union", OECD Economics Department Working Papers, No. 550, OECD, Paris.

Jaumotte, F. and P. Sodsriwiboon (2010), "Current Account Imbalances in the Southern Euro Area”, IMF Working Paper, No. 10/139, Washington DC.

Koske, I. et al. (2010), "The Impact of Structural Policies on Saving-Investment Gaps and Current Accounts", OECD Economics Department Working Papers, forthcoming, OECD, Paris.

Kumhof, M. and D. Laxton (2009), "Fiscal Deficits and Current Account Deficits", IMF Working Paper, No. 09/273, Washington DC.

Lamo, A., J. Perz and L. Schuknecht (2008), "Public and Private Sector Wages. Co-movement and Causality", European Central Bank Working Paper Series, No. 963.

Lane, P. (forthcoming), "International Financial Integration and the External Positions of Euro Area Member Countries", OECD Economics Department Working Papers, OECD, Paris.

Lucas, R. (1978), “Asset Prices in an Exchange Economy”, Econometrica, Vol. 46, No. 6, November.

Mundell, R. (1962), "The Appropriate Use of Monetary and Fiscal Policy Under Fixed Exchange Rates", IMF Staff Papers, No. 9, March, Washington.

Obstfeld, M. and K. Rogoff (1995), "Exchange Rate Dynamics Redux”, Journal of Political Economics, No. 102.

OECD (2004), OECD Employment Outlook, OECD, Paris.

OECD (2009a), OECD Economic Surveys: Italy, OECD, Paris.

OECD (2009b), OECD Economic Surveys: Ireland, OECD, Paris.

OECD (2009c), OECD Economic Surveys: Euro Area, OECD, Paris.

OECD (2010a), OECD Economic Outlook, No. 87, May, OECD, Paris.

OECD (2010b), OECD Economic Surveys: Germany, OECD, Paris.

OECD (2010c), OECD Economic Surveys: Portugal, OECD, Paris.

OECD (2010d), OECD Economic Surveys: Spain, OECD, Paris. 
Pain, N. et al. (2005), "The New International Trade Model”, OECD Economics Department Working Papers, No. 440, OECD, Paris.

Portes, R. (2001), "The European Contribution to International Financial Stability", CEPR Discussion Paper, No. 2956, September.

Rae, D. and P. van den Noord (2006),'Ireland's Housing Boom: What has Driven it and Have Prices Overshot?", OECD Economics Department Working Papers, No. 492, OECD, Paris.

Rajan, R. (2005), "Has Financial Development Made the World Riskier?”, NBER Working Paper, No. W11728, November.

Samuelson, P. (1964), "Theoretical Notes on Trade Problems", Review of Economics and Statistics, No. 46.

Schmitz, B. and J. von Hagen (2007), "Current Account Imbalances and Financial Integration in the Euro Area”, CEPR Discussion Paper Series, No. 7262, London.

Setzer, R., P. van den Noord and G. Wolff (2010), "Heterogeneity in Money Holdings across Euro Area Countries: the Role of Housing", European Economy Economic Papers, No. 407, February, Brussels.

van den Noord, P. (2005), "The Tax Incentives and House Price Volatility in the Euro Area: Theory and Evidence", Économie Internationale, Issue 1, No. 101.

Warin, T., P. Wunnava and H. Janicki (2009), “Testing Mundell's Intuition of Endogenous OCA Theory", Review of International Economics, Vol. 17, No. 1.

Williamson, J. (1983), The Exchange Rate System, Institute for International Economics, Washington DC. 


\section{Annex 1A.1}

Table 1A.1.1. Net financial assets by sector

\section{Per cent of GDP}

\begin{tabular}{|c|c|c|c|c|c|c|c|c|c|c|c|c|c|c|c|c|c|c|}
\hline & \multicolumn{3}{|c|}{ Total economy } & \multicolumn{3}{|c|}{ Non-financial corporations } & \multicolumn{3}{|c|}{ Households } & \multicolumn{3}{|c|}{ Government } & \multicolumn{3}{|c|}{ Net non-financial sector ${ }^{1}$} & \multicolumn{3}{|c|}{$\begin{array}{c}\text { International investment } \\
\text { position }\end{array}$} \\
\hline & 2002 & 2007 & $\begin{array}{l}\text { Change } \\
2007-02\end{array}$ & 2002 & 2007 & $\begin{array}{l}\text { Change } \\
2007-02\end{array}$ & 2002 & 2007 & $\begin{array}{l}\text { Change } \\
2007-02\end{array}$ & 2002 & 2007 & $\begin{array}{l}\text { Change } \\
2007-02\end{array}$ & 2002 & 2007 & $\begin{array}{l}\text { Change } \\
2007-02\end{array}$ & 2002 & 2007 & $\begin{array}{l}\text { Change } \\
2007-02\end{array}$ \\
\hline Austria & -20.3 & -9.1 & 11.2 & -80.6 & -94.5 & -13.9 & 97.1 & 114.0 & 16.9 & -37.2 & -30.7 & 6.4 & -20.7 & -11.2 & 9.5 & -21.2 & -19.8 & 1.4 \\
\hline Belgium & 43.0 & 33.2 & -9.8 & -78.1 & -103.5 & -25.3 & 215.5 & 212.1 & -3.4 & -93.3 & -73.3 & 19.9 & 44.1 & 35.3 & -8.8 & 41.3 & 31.4 & -9.9 \\
\hline Finland & -35.4 & -30.0 & 5.4 & -133.7 & -171.3 & -37.6 & 62.9 & 67.2 & 4.4 & 31.6 & 71.0 & 39.5 & -39.3 & -33.0 & 6.3 & -40.9 & -29.0 & 11.9 \\
\hline France & 12.9 & 14.3 & 1.4 & -74.8 & -115.6 & -40.8 & 115.9 & 133.0 & 17.1 & -41.8 & -34.0 & 7.8 & -0.7 & -16.6 & -15.9 & 3.0 & -0.3 & -3.3 \\
\hline Germany & -1.8 & 19.3 & 21.1 & -63.7 & -71.5 & -7.8 & 94.1 & 123.6 & 29.4 & -40.8 & -42.9 & -2.1 & -10.4 & 9.2 & 19.6 & 5.6 & 28.0 & 22.4 \\
\hline Greece & -56.2 & -100.5 & -44.4 & -61.7 & -92.8 & -31.0 & 107.4 & 92.3 & -15.2 & -94.7 & -70.4 & 24.3 & -49.0 & -70.9 & -21.9 & -58.9 & -101.9 & -43.0 \\
\hline Ireland $^{2}$ & -18.0 & -19.5 & -1.5 & -93.2 & -76.0 & 17.2 & 90.0 & 64.6 & -25.4 & -14.0 & 0.3 & 14.2 & -17.1 & -11.1 & 6.0 & -20.0 & -21.0 & -1.0 \\
\hline Italy & -4.3 & .7 & 5.0 & -103.7 & -105.2 & -1.5 & 193.6 & 188.6 & -5.1 & -95.7 & -87.1 & 8.6 & -5.8 & -3.7 & 2.1 & -15.3 & -23.1 & -7.8 \\
\hline Netherlands & -.9 & 44.1 & 45.0 & -99.8 & -86.8 & 13.1 & 155.7 & 168.9 & 13.2 & -60.3 & -37.4 & 22.9 & -4.4 & 44.7 & 49.1 & -27.0 & 5.9 & 33.0 \\
\hline Portugal & -56.6 & -90.6 & -34.0 & -146.0 & -167.8 & -21.8 & 129.8 & 127.6 & -2.2 & -34.4 & -44.2 & -9.8 & -50.6 & -84.4 & -33.8 & -62.6 & -98.3 & -35.6 \\
\hline Slovak Republic & -27.5 & -45.2 & -17.7 & -45.5 & -53.3 & -7.9 & 38.6 & 13.5 & -25.1 & -1.7 & 0.8 & 2.5 & -8.5 & -39.0 & -30.5 & -25.2 & -53.3 & -28.1 \\
\hline Spain & -38.4 & -77.0 & -38.6 & -96.0 & -157.3 & -61.3 & 94.1 & 95.5 & 1.3 & -40.3 & -19.0 & 21.4 & -42.2 & -80.8 & -38.6 & -46.9 & -83.4 & -36.5 \\
\hline Slovenia & -3.5 & -21.8 & -18.3 & -92.1 & -122.6 & -30.5 & 66.9 & 79.1 & 12.2 & 14.2 & 17.6 & 3.4 & -11.0 & -25.9 & -14.8 & 5.3 & 6.1 & 0.9 \\
\hline Euro area & -4.9 & -2.5 & 2.4 & -83.1 & -104.0 & -20.9 & 124.8 & 135.4 & 10.6 & -52.5 & -43.2 & 9.3 & -10.9 & -11.9 & -1.0 & & & \\
\hline
\end{tabular}

1. Sum of non-financial corporations, households and government.

2. Non-consolidated data.

Source: IMF (2010), International Financial Statistics; OECD (2010), National Accounts of OECD Countries - Financial Balance Sheets, Stocks, Vol. IIIb. 


\section{WORKING PAPERS}

The full series of Economics Department Working Papers can be consulted at www.oecd.org/eco/workingpapers/

826 Current account imbalances in the euro area: a comparative perspective (December 2010) by Sebastian Barnes, Jeremy Lawson and Artur Radziwill

825. Does fiscal decentralisation strengthen social capital? Cross-country evidence and the experiences of Brazil and Indonesia

(December 2010) by Luiz de Mello

824. Fiscal decentralisation and public investment: The experience of Latin America (December 2010) by Luiz de Mello

823. Product market regulation and competition in China

(December 2010) by Paul Conway, Richard Herd, Thomas Chalaux, Ping He and Jianxun Yu

822. Reforming China's monetary policy framework to meet domestic objectives (December 2010) by Paul Conway, Richard Herd and Thomas Chalaux

821. Regulatory reforms to unlock long-term growth in Turkey (December 2010) by Rauf Gönenç and Łukasz Rawdanowicz

820. After the crisis: mitigating risks of macroeconomic instability in Turkey (December 2010) by Łukasz Rawdanowicz

819. The 2008-09 crisis in Turkey: performance, policy responses and challenges for sustaining the recovery

(December 2010) by Łukasz Rawdanowicz

818. Fiscal-consolidation strategies for Canadian governments

(November 2010) by Yvan Guillemette

817. The land transport sector: policy and performance (November 2010) by Jan Persson and Daeho Song

816. A simple model of the relationship between productivity, saving and the current account (November 2010) by Jean-Marc Fournier, Isabell Koske

815. The impact of structural policies on saving, investment and current accounts (November 2010) by Clovis Kerdrain, Isabell Koske, Isabelle Wanner

814. Towards a less distortive and more efficient tax system in Portugal (November 2010) by Alvaro Pina

813. Are global imbalances sustainable? Shedding further light on the causes of current account reversals

(November 2010) by Luiz de Mello, Pier Carlo Padoan, Linda Rousová 
812. Turkey's improving integration with the global capital market: Impacts on risk premia and capital costs (November 2010) by Rauf Gönenç, Saygin Şahinöz, Özge Tuncel

811. Trade linkages in the OECD trade system (October 2010) by Jérôme Brézillon, Stéphanie Guichard and Dave Turner

810. Enhancing the effectiveness of social policies in Indonesia (October 2010) by Margherita Comola and Luiz de Mello

809. Tackling the infrastructure challenge in Indonesia (October 2010) by Mauro Pisu

808. Phasing out energy subsidies in Indonesia (October 2010) by Annabelle Mourougane

807. Implementing cost-effective policies in the United States to mitigate climate change (October 2010) by David Carey

806. Restoring fiscal sustainability in the United States (October 2010) by Patrick Lenain, Bob Hagemann and David Carey

805. Norway: Sustainable development: climate change and fisheries policies (September 2010) by Paul O’Brien

804. Netherlands: How the transport system can contribute to better economic and environmental outcomes

(September 2010) by Tomasz Koźluk

803. Public-private partnerships and investment in infrastructure (September 2010) by Sónia Araújo and Douglas Sutherland

802. Sustaining the momentum of fiscal reform (September 2010) by Colin Forthun and Robert Hagemann

801. The consequences of banking crises for public debt (September 2010) by Davide Furceri and Aleksandra Zdzienicka

800. A simulation model of federal, provincial and territorial government accounts for the analysis of fiscal-consolidation strategies in Canada (September 2010) by Yvan Guillemette

799. Product market regulation: extending the analysis beyond OECD countries (October 2010) by Anita Wölfl, Isabelle Wanner, Oliver Röhn, Giuseppe Nicoletti

798. Korea's green growth strategy: mitigating climate change and developing new growth engines (July 2010) by Randall S. Jones and Byungseo Yoo

797. Health-care reform in Korea

(July 2010) by Randall S. Jones 